\title{
CRÓNICA DE LA JURISPRUDENCIA CONSTITUCIONAL ESPAÑOLA EN EL AÑO 2015
}

\author{
Jurisprudential Chronicle of the Spanish Constitutional \\ Court in 2014
}

\author{
ALBERTO OEHLING DE LOS REYES' \\ Universidad de las Islas Baleares \\ aoelin@hotmail.com
}

Cómo citar/Citation

Oehling de los Reyes, A. (2016).

Crónica de la jurisprudencia constitucional española en el año 2015.

Anuario Iberoamericano de Justicia Constitucional, 20, 525-563.

doi: http://dx.doi.org/10.18042/cepc/aijc.20.18

\section{SUMARIO}

I. INTRODUCCIÓN. II. ALGUNAS CIFRAS. III. ANÁLISIS DE LA JURISPRUDENCIA: 1. Jurisdicción constitucional. Derecho procesal constitucional; 2. Fuentes del Derecho; 3. Estructura territorial del Estado; 4. Organización de los poderes públicos; 5 . Derechos fundamentales: 5.1. Derecho / principio de igualdad; 5.2. Libertad ideológica y religiosa; 5.3. Derechos de libertad personal; 5.4. Intimidad; 5.5. Libertad de expresión; 5.6. Tutela judicial efectiva; 5.7. Derecho a la legalidad. IV. RECAPITULACIÓN Y CONCLUSIONES. V. BIBLIOGRAFÍA.

\section{INTRODUCCIÓN}

En 2015, por desgracia, se ha vuelto a producir una baja en el Tribunal Constitucional por el triste fallecimiento, el 15 de abril de 2015, en acto de

\footnotetext{
1 Profesor contratado doctor de Derecho constitucional de la Universidad de las Islas
} Baleares (España). 
servicio, del magistrado Luis Ignacio Ortega Álvarez. No se ha producido aquí una sustitución extraordinaria, como en el caso de Francisco Hernando, que se suplió más o menos con carácter inmediato - por la vía del art. 16.5 de la LOTC_- a los dos meses y medio, con el nombramiento por el Senado de Ricardo Enríquez Sancho. Posiblemente la razón de esta demora se haya debido a la proximidad del fin de la legislatura, que ha llevado a una postergación de la sustitución una vez se configuraran las Cortes tras los resultados de las elecciones generales del 20 de diciembre de 2015. Después, el carácter fragmentado de las nuevas Cámaras, la imposibilidad de obtener un Gobierno en mayoría, la disolución del Parlamento, la repetición de elecciones generales el 6 de junio de 2016 y el retraso añadido de constitución del nuevo Congreso y Senado, apuntan a que el nombramiento ya se dejará para finales de 2016, haciéndolo coincidir con la expiración del mandato de los otros magistrados de proveniencia del Senado (Francisco Pérez de los Cobos, Adela Asúa y el propio Ricardo Enríquez), que estaban en el cargo por un periodo de solo seis y dos años, respectivamente, no de nueve como establece el art. 159.3 de la Constitución, de conformidad con el inciso final del art. 16.5 de la LOTC. Así pues, desde abril de 2015, hemos vuelto a tener una magistratura desequilibrada y es más que posible que esto permanezca así durante algún tiempo más, en concreto hasta que toque su renovación finales de 2016 e inicios de 2017-y las fuerzas políticas con representación en el Senado las asambleas legislativas de las comunidades autónomas, de conformidad con el art. 16.1 de la LOTC, lleguen a un acuerdo para llevar a cabo la renovación.

Respecto a la LOTC, cabe citar, aunque sea brevemente, algunas cuestiones de interés, pues 2015 ha sido año de algunos cambios. En primer lugar, la Ley Orgánica 12/2015, de 22 de septiembre, de modificación de la Ley Orgánica 2/1979, de 3 de octubre, del Tribunal Constitucional, para el establecimiento del recurso previo de inconstitucionalidad para los proyectos de ley orgánica de estatuto de autonomía o de su modificación, que ha añadido un título VI bis y un nuevo art. 79 (que había quedado sin contenido desde la Ley Orgánica 4/1985, de 7 de junio), y que regula el nuevo control previo de inconstitucionalidad de los proyectos de estatutos de autonomía y sus propuestas de reforma, en particular, los posibles proyectos de estatuto o de propuestas de reforma de estatutos que se puedan suceder a partir de ahora, una vez se produzca su tramitación en ambas Cámaras de las Cortes Generales. En segundo lugar, la Ley Orgánica 15/2015, de 16 de octubre, de reforma de la Ley Orgánica 2/1979, de 3 de octubre, del Tribunal Constitucional, para la ejecución de las resoluciones del Tribunal Constitucional como garantía del Estado de derecho, por la que se determina una nueva redacción de algunos aspectos de los arts. 80, 87, 92 y 95 de la LOTC y que perfilan aún más en el 
ordenamiento jurídico el carácter ejecutivo de sus resoluciones ${ }^{2}$. La modificación incluye, grosso modo, funciones de auxilio jurisdiccional a fin de que el Tribunal pueda acometer la ejecución de sus resoluciones, determina en este marco la aplicación supletoria de la Ley de la Jurisdicción Contencioso-administrativa y, para casos de incumplimiento, la posibilidad de imponer multas coercitivas, acordar la suspensión de las autoridades o empleados públicos, y la facultad de exhortar al Gobierno de la nación la preceptiva ejecución sustitutoria ${ }^{3}$. Hizo bastante ruido esta reforma y despertó algunas críticas entre políticos e incluso juristas por la sorpresa que puede suponer en nuestro país que el Tribunal Constitucional pueda tener mayores instrumentos cara a la implementación efectiva y en mayor grado de sus resoluciones. No obstante, hay que tener también en cuenta que el Tribunal Constitucional ha admitido a trámite dos recursos de inconstitucionalidad interpuestos por el Gobierno vasco y la Generalitat de Cataluña contra dicha reforma (Providencias de 2 de febrero de 2016).

Como es habitual en esta crónica, la breve selección de sentencias que aquí se presenta se basa, fuera de la sucesión de sentencias que el Tribunal Constitucional ofrece en su página web, fundamentalmente, como en años anteriores, en la Memoria y estadística del Tribunal del año $2015^{4}$, en las relaciones de sentencias elaboradas por el Departamento de Derecho constitucional de la Universidad Carlos III de Madrid ${ }^{5}$ y en los excepcionales estudios cuatrimestrales realizados por Juan Luis Requejo, Juan Carlos Duque Villanueva, Carlos Ortega y Marian Ahumada, para la Revista Española de Derecho Constitucional', aunque también hemos tenido en cuenta la selección jurisprudencial de la revista trimestral Otrosí, del Colegio de Abogados

2 En relación con la adscripción política de los magistrados del Tribunal Constitucional, no tuvo suerte la propuesta de modificación del art. 19.1 de la LOTC, dirigida a prohibir que estos, más allá de la posibilidad de asumir funciones directivas en formaciones de partidos — como ya establece el precepto-, pudieran simplemente pertenecer a partidos políticos o sindicatos. Véanse las enmiendas al articulado a la Proposición de Ley Orgánica de Reforma de la Ley Orgánica 2/1979, de 3 de octubre, del Tribunal Constitucional, en el BOCG, Congreso de los Diputados, núm. 162-4, de 6 de julio de 2015, págs. 14 y 15. Sobre este tema, véase Oehling de los Reyes (2014).

3 Sobre las novedades de la norma puede verse, por ejemplo, González Hernández (2016).

4 Tribunal Constitucional (2015).

5 Elvira Perales et al. (2015a; 2015b; 2015c).

6 Requejo Pagés et al. (2015a; 2015b; 2015c). 
de Madrid 7 , y el compendio de fallos incluido en El Notario del Siglo XXI . Igualmente, en algún caso particular — como se irá viendo—, se ha utilizado algún estudio científico y doctrinal que desarrolla y profundiza alguna de las resoluciones de 2015.

\section{ALGUNAS CIFRAS}

En el año 2015 ingresaron en el Tribunal 42 recursos de inconstitucionalidad, 112 cuestiones de inconstitucionalidad, una cuestión de inconstitucionalidad impropia, 7203 recursos de amparo, cinco conflictos positivos de competencia, dos conflictos en defensa de la autonomía local, una impugnación de disposiciones sin fuerza de ley o resoluciones de las comunidades autónomas y tres cuestiones prejudiciales sobre normas forales. El cómputo total de asuntos del año pasado, por tanto, da una cifra de 7369 y presupone, a diferencia de la línea de años anteriores, que se ha producido una bajada de entrada de casos respecto al año 2014, en el que el total de causas que entraron en el Tribunal fue de 7878. La principal razón de dicha bajada se debe al descenso significativo de solicitudes de amparo, habiéndose presentado en 2015 un número de 7203 demandas, frente a las 7663 de 2014. En 2015, según la Memoria anual, únicamente fueron admitidos para su subsiguiente conocimiento y resolución un total de 84 recursos de amparo, cifra que supone solamente el 1,06\%. Ya en 2014, el Consejo General de la Abogacía Española ponía de manifiesto que solamente un 1,08 \% de los recursos de amparo pasaba la fase de trámite ${ }^{9}$. Quizás la razón del descenso de interposición de procedimientos en amparo se deba a que estas cifras empujen desde el principio a un cierto desistimiento previo de presentación por parte de letrados por las escasas posibilidades de éxito en la fase de admisión a trámite; si bien no es menos cierto - como señala el presidente del Tribunal en el mismo prólogo de la Memoria - que hay un alto porcentaje de recursos que tienen como causa de inadmisión el incumplimiento por las demandas de requisitos legales exigidos para su admisión a trámite, en particular la falta de justificación de la especial trascendencia constitucional del objeto del recurso del art.

7 Véase la sección de Novedades jurisprudenciales de Otrosí, 7, 8 y 9 (2015), Ilustre Colegio de Abogados de Madrid, respectivamente, págs. 63-64, 67-69 y 67-70.

8 Llorente Gonzalvo y López Mejía (2015a; 2015b; 2015c; 2015d; 2015e; 2015f).

9 Véase la noticia «El TC sólo admitió poco más del uno por ciento de los recursos de amparo en 2014», en la página web del CGAE, en http://www.abogacia.es. 
49.1 de la LOTC, falta esta que este año todavía ha dado lugar a un $16,67 \%$ de inadmisiones.

Hay que decir, por otra parte, que a finales de 2015 todavía se hallaban admitidos a trámite, pero pendientes de resolución, teniendo en cuenta los procesos acumulados, un total de 163 recursos de inconstitucionalidad, 47 cuestiones de inconstitucionalidad, 24 conflictos positivos de competencia, cuatro conflictos en defensa de la autonomía local y tres cuestiones prejudiciales sobre normas forales fiscales. En cambio, los procesos de amparo pendientes de sentencia completaban un total de 88 asuntos (99 con los avocados). Hay que sumar aquí también las causas de constitucionalidad pendientes de admisión y que sumaban 57 asuntos de débito (dos recursos de inconstitucionalidad y 55 cuestiones de inconstitucionalidad), mientras que los recursos de amparo pendientes de admisión por las salas daban un resultado de 3312 asuntos (1770 correspondientes a la Sala Primera y 1542 de la Sala Segunda).

\section{ANÁLISIS DE LA JURISPRUDENCIA}

\section{JURISDICCIÓN CONSTITUCIONAL. DERECHO PROCESAL CONSTITUCIONAL}

La Ley Orgánica 6/2007, de 24 de mayo, dio nueva redacción al art. 49.1 de la Ley Orgánica 2/1979, de 3 de octubre, del Tribunal Constitucional, y desde entonces, el Tribunal ha ido dando sentido al requisito de «especial trascendencia constitucional» que tal art. determina como ineludible, cara a la admisibilidad de la petición de amparo. Ahora, el Tribunal de Estrasburgo, en la STEDH de 20 de enero de 2015 (asunto Arribas Antón c. España), ha refrendado de alguna manera el desarrollo dado por el Tribunal Constitucional a este respecto. En efecto, el TEDH reconoce el derecho de los Estados a establecer determinados filtros de admisibilidad en materia de recursos, si bien, en el caso de cláusulas formales de este tipo, siempre se ha de ir definiendo - como hace el Tribunal Constitucional - el contenido y el alcance de las mismas y, asimismo, explicitando su carácter y aplicación en los asuntos declarados admisibles con el fin de garantizar una buena administración de la justicia. A juicio del Tribunal de Estrasburgo, «el hecho de subordinar la admisibilidad de un recurso de amparo a la existencia de circunstancias objetivas y a su justificación por parte del recurrente, siendo estos criterios previstos por la ley e interpretados por la jurisprudencia constitucional - tales como la trascendencia de la causa para la interpretación, la aplicación o la eficacia general de la Constitución o para determinar el contenido y el alcance 
de los derechos - no es, como tal, desproporcionado o contrario al derecho de acceso al Tribunal Constitucional» ${ }^{10}$.

El Tribunal Constitucional ha seguido, por tanto, intentando conceptuar esta obligación del recurrente, hacerla más fácilmente comprensible y determinar su casuística, ahora también con base en la resolución del TEDH sentada en el caso Arribas Antón c. España, muy en particular en la STC 9/2015 (Sala Primera), de 2 de febrero, donde nos dice que aunque la especial trascendencia constitucional constituye un requisito de admisión de la demanda que es objeto de valoración ya en el trámite de admisión del recurso, ello no es óbice para que, después, sucesivamente, el Tribunal explicite mayormente el cumplimiento de este requisito como «exigencia de certeza [...], haciendo así reconocibles los criterios de aplicación empleados al respecto por este Tribunal (STEDH) de 20 de enero de 2015, asunto Arribas Antón c. España)». Asimismo, en su STC 54/2015 (Sala Segunda), de 16 de marzo, ha vuelto a repetir que el requisito puede quedar cubierto ya de por sí en casos de renuencia en fase ordinaria por el juzgador del deber de acatamiento de la doctrina constitucional, por ejemplo, en lo que se refiere a la doctrina en materia del derecho a la inviolabilidad del domicilio, el secreto de las comunicaciones, obtención de prueba, validez de la confesión e interrogatorio y habeas corpus (STC 42/2015 [Sala Segunda], de 2 de marzo). Luego, en su STC 124/2015 (Sala Segunda), ha determinado también como «suficiente», para justificar la proyección objetiva del amparo solicitado y entender satisfecha la carga de justificar la especial trascendencia constitucional del art. 49.1 in fine de la LOTC, la petición de que el Tribunal «aclare y confirme el derecho a obtener justicia gratuita en cualquier instancia, exponiendo la proyección que tiene esta interpretación en el cierre del acceso al recurso de apelación». A juicio del Tribunal, este tipo de petición que permite conectar materialmente la lesión alegada con la necesidad de una decisión sobre el fondo en razón de su especial trascendencia constitucional - conforme a lo establecido en la STC 155/2009, de 25 de junio, a saber, que el recurso plantea un problema o faceta nueva de un derecho fundamental-, ofrece bastante base a estos efectos. Y algo similar ocurre en la STC 226/2015 (Sala Segunda), de 2 de noviembre, donde el petitum de la demanda está en la solicitud al Tribunal, en mayor o menor grado expresada, de perfilar y consolidar su doctrina sobre la exigencia de un deber reforzado de motivación en el supuesto concreto de proposición de indulto del art. 206 del Real Decreto 190/1996, de 9 de febrero, que aprueba el Reglamento Penitenciario. Existe, por lo tanto, un sustrato de admisibilidad que debe determinar el Tribunal, en el que la necesidad de

10 Sobre ello, Rodríguez-Piñero y Bravo-Ferrer (2015). 
perfeccionar una determinada problemática en ciertos conceptos jurídicos de dispar aplicación por parte del Tribunal Constitucional puede llevar a su comprensión como elemento suficiente de realización del requisito del art. 49.1 LOTC.

En materia de formalidades referidas a la cuestión de inconstitucionalidad, destaca la STC 50/2015 (Pleno), de 5 de marzo. Se daba la vicisitud de que el Decreto 140/1998, de 16 de julio, por el que se aprobaba el plan de ordenación de los recursos naturales de Fuentes Carrionas y Fuente Cobre-Montaña en Palencia, y que tenía por objeto posibilitar la creación de una nueva estación de esquí en Castilla y León, fue anulado por la Sala de lo Contencioso-Administrativo del TSJ de Castilla y León el 8 de enero de 2008; luego le seguiría la STS de 25 de enero de 2012 que ratificaría la nulidad de la disposición reglamentaria. A efectos de soslayar la nulidad determinada por vía de control judicial en 2008 y a la vista de lo que podría pasar en el TS, el legislativo de la Comunidad Autónoma de Castilla y León aprobó la Ley 5/2010, de 28 de mayo, de modificación de la Ley 4/2000, de 27 de junio, de declaración del parque natural de Fuentes Carrionas y Fuente Cobre-Montaña Palentina, que venía a repetir lo dicho en la norma reglamentaria, suprimiendo ya directamente sin reparos la prohibición de instalación de estaciones de esquí alpino en el parque. Ante esta situación, la parte - distintas asociaciones de protección de la naturaleza-, promovió incidente de ejecución de la Sentencia de 8 de enero de 2008, a efectos de que se declarase la imposibilidad de realización de la misma por vía de lo ahora promulgado en la Ley 5/2010, de 28 de mayo; y, solicitando, a la par, que, en el momento de resolver el incidente, se planteara por la Sala cuestión de inconstitucionalidad sobre la citada norma. En opinión del Tribunal — que acaba por estimar la cuestión y declarar inconstitucional la Ley de Castilla y León 5/2010, de 28 de mayo-, esta redirección peculiar de la cuestión «es, en este aspecto, correcta, ya que, dependiendo —en la interpretación del Tribunal Superior de Justicia—, la decisión del incidente ejecutorio de la validez de la Ley 5/2010, en la medida en que es preciso determinar su incidencia en la efectividad de lo previamente resuelto, concurren los presupuestos para el acceso ante la instancia constitucional a través del cauce de la cuestión de inconstitucionalidad».

Respecto a impugnación de disposiciones sin fuerza de ley y resoluciones de las comunidades autónomas prevista en el art. 161.2 de la Constitución, hay que citar la STC 32/2015 (Pleno), de 25 de febrero. Es conocido el deslinde típico de fórmulas de impugnación constitucional según el objeto del recurso: recurso de inconstitucionalidad contra las leyes, disposiciones normativas o actos con fuerza de ley (art. 31 de la LTC) y conflictos de competencia, para casos de impugnación de decisiones, actos o resoluciones emanados de las comunidades autónomas o del Estado que presupongan disyuntivas por 
razones de competencia. Ahora bien, cuando el caso de enjuiciamiento sea híbrido, en el sentido de contener una impugnación de disposiciones por la vía del art. 161.2 de la Constitución, a la par que ciertos aspectos de índole competencial, el Ejecutivo puede hacer uso también de esta vía peculiar, determinada en el título V de la LOTC, si bien — especifica el Tribunal— «los requisitos procesales que debe cumplir para que la impugnación sea admitida a trámite son los mismos que los establecidos para que el Gobierno pueda plantear directamente el conflicto positivo de competencias: el plazo para recurrir es, en ambos supuestos, de dos meses (arts. 62 y 76 LOTC), y la impugnación, por expresa disposición del art. 77 de la LOTC, sea cual fuere el motivo en que se base debe formularse y sustanciarse por el procedimiento previsto en los arts.62 a 67 de la LOTC, que es por el que se tramitan los conflictos positivos de competencias».

Sobre el marco y forma de admisibilidad de procedimientos por conflictos en materia local, también debemos reseñar la STC 92/2015 (Pleno), de 14 de mayo. Varios ayuntamientos de Cantabria habían impugnado la Ley del Parlamento de Cantabria 2/2004, de 27 de septiembre, del Plan de Ordenación del Litoral, por vía del capítulo IV del título IV de la LOTC, que hilvana el procedimiento en defensa de la autonomía local. A juicio de las entidades locales recurrentes, la norma vulneraba el principio de autonomía local reconocida en el art. 140 de la Constitución. Y es que, en opinión de dichos municipios, el plan había sido aprobado por ley pero soslayando el cumplimiento de trámites y requisitos esenciales establecidos por el ordenamiento jurídico precisamente para preservar la autonomía municipal; por ejemplo, para modificar el anteproyecto de ley, ni se había pasado el trámite de nueva audiencia a los ayuntamientos afectados. El Gobierno de la Comunidad Autónoma de Cantabria interesaba la validez de la norma y la improcedencia del conflicto sobre la base de dos motivos de calado dispar. En primer lugar, se alegaba incluso la inconstitucionalidad del mismo conflicto en defensa de la autonomía local que había aparecido tras la reforma de la LOTC operada por la Ley Orgánica 7/1999, de 21 de abril. Desde su peculiar interpretación, este instrumento no entra dentro de las competencias literalmente determinadas del Tribunal Constitucional del art. 161 de la Constitución, razón por la cual su previsión posterior por la LOTC no era válida, dando a entender, de soslayo, que la vía de inclusión de este tipo de recurso en el ordenamiento jurídico se hubiera debido de hacer por reforma constitucional y no de la LOTC. La representación del Ejecutivo de Cantabria obviaba así, arteramente, la posibilidad reconocida en el mismo art. 161.1.d de la Constitución, que reconoce que el Tribunal es también competente para conocer de aquellas otras materias que le vengan dadas por norma orgánica. El Tribunal, vuelve sobre su jurisprudencia ya de sobra conocida en esta materia (SSTC 240/2006, de 20 de julio, y 47/2008, 
de 11 de marzo), reiterando que lo cierto es que el legislador orgánico está perfectamente legitimado por la propia norma constitucional para atribuir a la jurisdicción del Tribunal Constitucional la competencia para conocer de otras materias, aun cuando no estén contempladas en ese u otros preceptos constitucionales, siempre que dicha atribución no se haga contra la Constitución. En segundo lugar, la queja del Ejecutivo autonómico versaba sobre el art. 75 ter de la LOTC, en cuanto este exige «únicamente la adopción de un acuerdo plenario de las corporaciones locales para iniciar la tramitación de los conflictos en defensa de la autonomía local». A su entender, a tales efectos de decidir sobre la presentación del conflicto, se debería recabar la existencia de dos acuerdos plenarios: uno a la hora de iniciar la tramitación del conflicto en defensa de la autonomía local (art. 75 ter.2), y, después, uno segundo, en orden a la pertinencia de planteamiento del conflicto ante el Tribunal Constitucional (art. 75 quater.2). Como quiera que ese segundo acuerdo no se ha adoptado por ninguno de los municipios promotores del conflicto, habría de acordarse, siempre en opinión del Ejecutivo autonómico, la inadmisión del conflicto, de conformidad con lo dispuesto en los arts. 75 ter, 75 quater y 75 quinquies. 1 de la LOTC. El Tribunal tampoco aquí da la razón a la contraparte, dando por bueno el requisito del art. 75 ter LOTC, que únicamente exige la adopción de un acuerdo plenario de las corporaciones locales, con aprobación de la mayoría absoluta del número legal de sus miembros — como había sido el caso-, a efectos de iniciación de la tramitación de los conflictos en defensa de la autonomía local.

Hay que señalar en este punto también la STC 195/2015 (Sala Primera), de 21 de septiembre. La causa trae origen de un recurso contencioso-administrativo en el que la parte actora decía que la Orden de 26 de marzo de 2007 de la Consejería de Vivienda y Urbanismo que aprobaba definitivamente el plan de ordenación municipal de Toledo era nulo de pleno derecho porque se habían realizado modificaciones sustanciales sin someterlo nuevamente al trámite de información pública. La representación del Ayuntamiento de Toledo justificaba esta omisión sobre la base del art. 36.2.a del Decreto Legislativo 1/2010, de 18 de mayo, por el que se aprueba el Texto Refundido de la Ley de Ordenación del Territorio y de la Actividad Urbanística de Castilla la Mancha, que determina causas de limitación del trámite de audiencia. Lo Contencioso-Administrativo del TSJ de Castilla-La Mancha, dictó fallo a favor de la actora — sobre la base de que el art. 6 de la Ley 6/1998, de 13 de abril, sobre régimen del suelo y valoraciones (hoy derogada), es más exigente en orden a la cumplimentación de este requisito-, razón por la cual la representación del Ayuntamiento formularon recurso de casación y afirmaban que el TSJ había incurrido en un exceso de jurisdicción al estar obligada a aplicar el art. 36.2.a del texto refundido de la Ley de ordenación del territorio y de la actividad 
urbanística, y que de no hacerlo — por entender que adolecía de algún tipo de ilicitud - lo que tenía que haber hecho la Sala era plantear la cuestión de inconstitucionalidad conforme a lo dispuesto en los arts. 163 de la Constitución y 35.1 de la LOTC y 5.2 de la LOPJ. El Tribunal Supremo desestimó el recurso de casación; luego también inadmitió el incidente de nulidad de actuaciones (art. $241 \mathrm{LOPJ}$ ), interpuesto por la representación de Toledo, en el que se solicitaba que se dictase una nueva sentencia respetuosa con los arts. 24.1 y 2 de la Constitución. Así las cosas, la representación del Ayuntamiento de Toledo va al amparo para que se analice la posibilidad de inaplicación judicial de una ley autonómica sin planteamiento de la correspondiente cuestión de inconstitucionalidad. El Tribunal, en el cuerpo del fallo, va respondiendo sucesivamente a cada una de las disyuntivas planteadas. En primer lugar, el Pleno analiza el alcance de la legitimación activa del Ayuntamiento de Toledo para impetrar amparo constitucional frente a las resoluciones impugnadas. El Tribunal recuerda que su doctrina ya ha reconocido la legitimación activa de una comunidad autónoma para acudir en amparo para cuestionar la inaplicación de una ley autonómica, y de ello deduce que el Ayuntamiento de Toledo también goza, frente a decisiones de inaplicación de leyes autonómicas, de análoga legitimación activa, por cuanto «la parte actora es una Administración pública que impetra el auxilio del Tribunal en defensa de un acto dictado en el ejercicio de sus potestades administrativas (planeamiento urbanístico)», y, además, busca garantizar su "derecho a no sufrir indefensión». En segundo lugar, analiza si la presentación del incidente de nulidad de actuaciones puede conllevar extemporaneidad del recurso. El Tribunal no lo ve así, puesto que la propia Sala del Supremo lo admitió a trámite, dio traslado de la pretensión anulatoria a las demás partes, entró a conocer sobre el fondo de las quejas formuladas por el demandante y, finalmente, lo desestimó. En tercer lugar, el Pleno analiza el proceso aplicativo de las leyes en intersección, los límites de las facultades inherentes a la potestad de juzgar, de las capacidades del juez ordinario de elegir la norma jurídica aplicable al caso concreto de entre las varias posibles (el Texto Refundido o la Ley 6/1998), cuando las mismas son normas con rango de ley, y, si en este caso, conviene el planteamiento de la cuestión de inconstitucionalidad. A este respecto, el Pleno da su respuesta salomónica: «Comprobar si la calificación de lo básico realizada por el legislador ha sido correcta es función privativa de este Tribunal (STC 156/1995, de 26 de octubre), que es a quien le corresponde determinar si la norma estatal se desenvuelve dentro del marco de las competencias del Estado y en consecuencia si la legislación autonómica infringe el bloque de distribución de competencias. De lo que se sigue que los órganos judiciales al inaplicar la norma legal autonómica por considerarla contraria a las bases estatales, sin plantear la cuestión de inconstitucionalidad, han desbordado los contornos 
propios de su potestad jurisdiccional (art. 117.1 de la Constitución), y con ello han vulnerado los derechos fundamentales consagrados en los arts. 24.1 y 24.2 de la Constitución».

La STC 238/2015 (Pleno), de 19 de noviembre, también puede citarse dentro de este apartado. Se trata de un caso que resuelve un recurso de inconstitucionalidad del Ejecutivo contra la Ley 9/2015, de 12 de junio, de modificación de la Ley 7/2007, de la Agencia Tributaria de Cataluña. El precepto impugnado establecía la posibilidad per saltum de ir del Cuerpo Superior de Inspectores de Hacienda del Estado de la Agencia Tributaria al Cuerpo Superior de Inspectores Tributarios de la Comunidad Autónoma, de forma similar a como ya establecen algunas otras normas autonómicas de análogo tenor como la Ley 3/2007, de 27 de marzo, de la Función Pública de la Comunidad Autónoma de las Illes Balears, y como la Ley 10/2010, de 9 de julio, de Ordenación y Gestión de la Función Pública Valenciana; siendo esta razón una de las causas por las que la representación de la Comunidad Autónoma de Cataluña proponía la licitud de la norma. El Tribunal —y esto es lo que aquí interesa- fuera de las razones que empujan al Pleno a declarar la inconstitucionalidad del art., recuerda el concepto de «justicia rogada» como base de su actuación, también en relación con la facultad del Ejecutivo de interposición de la duda de constitucionalidad, no pudiendo, por tanto, «enjuiciar la constitucionalidad del régimen jurídico de normas que no han sido objeto de este concreto proceso». O sea, que hay que huir de interpretaciones que dan por buena una norma por el simple hecho de que sea válida en otra comunidad autónoma o no haya sido recurrida en sede constitucional en anteriores legislaturas por un Ejecutivo, entendiendo que el Gobierno puede ejercer o no esta facultad de recurso dependiendo del caso y de distintos factores.

Sobre las características de juridicidad que debe revestir una declaración de una comunidad autónoma para ser objeto de impugnación ante el Tribunal Constitucional, cabe citar la STC 259/2015 (Pleno), de 2 de diciembre. El Pleno recuerda algún fallo al respecto, indicando que a efectos de planteamiento de duda de constitucionalidad basta con que la norma en disyuntiva, aparte de naturaleza jurídica, sea fruto, además, de la manifestación de la voluntad institucional de una comunidad autónoma, esto es, que proceda de órganos capaces de expresar la voluntad de esta, no sea un mero acto de trámite y, por último, que tenga, siquiera indiciariamente, capacidad para producir efectos jurídicos (ATC 135/2004, de 20 de abril). El Tribunal entiende que, aparte, también se ha de analizar la irradiación de efectos políticos del contenido de la misma más allá del marco de la asamblea legislativa de la comunidad autónoma donde se emite, así como si de ella derivan otro tipo de acciones concretas para su desarrollo y si ese despliegue queda sujeto al control parlamentario previsto para este tipo de resoluciones aprobadas por la cámara. 
Cumplidos estos requisitos, se comprende la idoneidad de una resolución del tipo como posible objeto del proceso constitucional de los arts. 161.2 de la Constitución y 76 y 77 de la LOTC.

\section{FUENTES DEL DERECHO}

Hay cuestiones iusconstitucionales que quedan perfectamente reflejadas en la Constitución que, de plano, no están previstas en nuestro sistema constitucional ni legal. En efecto, el art. 92 de la Constitución es rotundo y taxativo: por un lado, su inciso $2^{\circ}$ dice que «el referéndum será convocado por el Rey, mediante propuesta del presidente del Gobierno, previamente autorizada por el Congreso de los Diputados»; por otro lado, su inciso final establece también que «una ley orgánica regulará las condiciones y el procedimiento de las distintas modalidades de referéndum previstas en esta Constitución». Luego, aparte, hay que decir que el art. 149.1.32 de la Constitución determina como competencia exclusiva del Estado la «autorización para la convocatoria de consultas populares por vía de referéndum». La Ley del Parlamento de Cataluña 10/2014, de 26 de septiembre, de consultas populares no refrendarias y otras formas de participación ciudadana trata en cambio de convencer como dejan entrever las alegaciones de parte en los antecedentes del fallo- de la posibilidad de que existan otro tipo de referéndums sui generis, compatibles con esa normativa básica y reducida al ámbito de consulta municipal. Los arts. impugnados incluyen los temas sobre los que puede versar una consulta, sus formalidades, límites, formas de emisión del voto, participantes, medios de registro, en fin, vuelven sobre todos los elementos que permiten definir un referéndum. El fallo del Tribunal al respecto (STC 31/2015 [Pleno], de 25 de febrero), asistido por la rotundidad de reserva de ley orgánica del art. 92 de la Constitución, tal y como también establece la STC 31/2010, de 28 de junio, determina, como era previsible ${ }^{11}$, la inconstitucionalidad y nulidad de los preceptos impugnados. «El legislador autonómico — dice el Pleno de forma taxativa - ha ignorado las consecuencias que se derivan de los arts. 23.1 y 149.1.1 de la Constitución en relación con el art. 81.1 (regulación por ley orgánica del derecho fundamental de participación en los asuntos públicos), del art. 92.3 (regulación por ley orgánica de las condiciones y procedimiento de las distintas modalidades de referéndum previstas en la Constitución) y del art. 149.1.32 de la Constitución, que atribuyen al Estado una competencia exclusiva que, como ya hemos repetido, no se limita a la autorización estatal para la convocatoria de consultas populares por vía de referéndum, sino que

11 Así, Arbós Marín (2015). 
«se extiende a la entera disciplina de esa institución, esto es, a su establecimiento y regulación» (STC 31/2010, de 28 de junio, FJ 69)».

Relacionada con la teoría de los límites materiales de las leyes de presupuestos hay que indicar la STC 44/2015 (Pleno), de 5 de marzo, que versa también sobre la nulidad de un precepto de ley anual presupuestaria que limitaba la capacidad del Parlamento de regular el procedimiento de determinación del objetivo de estabilidad presupuestaria. La causa devenía de un recurso de inconstitucionalidad frente a distintos preceptos de la Ley 2/2004, de 24 de diciembre, de Presupuestos Generales del Estado para 2005, al considerar que vulneraban los arts. 9.3, 14, 31.1 y 3, 66.2, y 134.2, 6 y 7 de la Constitución y los arts. 69 y 133.3 del Reglamento del Congreso. El recurso incluía quejas por lagunas en la información a las Cámaras de las cifras de ingresos y gastos, propaso en el contenido típico de la norma de presupuestos, distribución opaca de gastos entre ministerios y otras anomalías en la contabilidad del volumen de ventas al Servicio Nacional de Salud y, aparte, en materia de procedimiento introducía una modificación de la Ley 18/2001 de 12 de diciembre, general de estabilidad presupuestaria, que afectaba en cierta forma a la rutina de trabajo parlamentario, por cuanto limitaba la intervención del Senado en orden a su capacidad para la fijación del objetivo de estabilidad presupuestaria. El Tribunal no reconoce la inconstitucionalidad de las normas objeto de recurso; por razones diversas, bien por no constatarse de forma fehaciente y acreditada las irregularidades planteadas o por entender que las materias acusadas de propaso se pueden comprender, de uno u otro modo, como objeto de una ley anual de presupuestos. Por el contrario, sí declara como inconstitucional la modificación colateral de la Ley 18/2001, de 12 de diciembre, General de Estabilidad Presupuestaria, por entender que, por un lado, realmente, tiene difícil encaje en una norma económica o presupuestaria $y$, por otro, por apreciar que en el fondo dicha reforma normativa afectaba a la autonomía reglamentaria de la Cámara, ya que establecía una regulación del procedimiento parlamentario de aprobación de los presupuestos generales que, por su incidencia en el proceso de elaboración legislativa, queda reservada al desarrollo normativo de las propias Cámaras de acuerdo con el art. 72.1 de la Constitución.

En materia de irretroactividad como principio y límite de las normas restrictivas de derechos individuales cabe reseñar la STC 49/2015 (Pleno), de 5 de marzo. El fallo deviene de otro típico recurso de inconstitucionalidad interpuesto por más de 50 diputados contra el art. 2.1 del Real Decreto Ley 28/2012, de 30 de noviembre, de medidas de consolidación y garantía del Sistema de la Seguridad Social. A juicio de los recurrentes, la norma dejaba sin efecto para el ejercicio 2012 la actualización de las pensiones para el caso de que el índice de precios al consumo (IPC) correspondiente al pe- 
ríodo comprendido entre noviembre del ejercicio anterior y noviembre del ejercicio económico en curso fuera superior al IPC previsto y en función del cual se calcula la revalorización de la pensión; luego, decían, asimismo, que el citado precepto vulneraba el art. 9.3 de la Constitución, al establecer una retroactividad auténtica contraria al derecho, constitucionalmente reconocido en el art. 50 de la Constitución, a la percepción de una pensión periódica y actualizada. Para el año 2012 las pensiones se habían revalorizado un $1 \%$, pero el IPC acumulado de noviembre de 2011 a noviembre de 2012 resultaba ser un $2,9 \%$, y, en consecuencia — de conformidad con lo previsto en los arts. 48.1.2 del texto refundido de la Ley General de la Seguridad Social, aprobado por Real Decreto Legislativo 1/1994, de 20 de junio, y el art. 27.1 de la Ley de Clases Pasivas del Estado, aprobado por Real Decreto Legislativo 670/1987, de 30 de abril- debería haberse procedido, en principio, a la correspondiente actualización. Sin embargo, el Real Decreto Ley 28/2012, de 30 de noviembre, dejó sin efecto la actualización de las pensiones conforme al IPC real en dicho ejercicio, con lo cual el Ejecutivo del momento se ahorraba una cantidad millonaria cara a la crisis. El Pleno, en cambio, no da la razón a los recurrentes. A su juicio los arts. que dan cobertura al recurso (arts.48.1.2 de la Ley General de la Seguridad Social y 27.1 del texto refundido de la Ley de clases pasivas del Estado) «no proceden a reconocer de forma automática a los pensionistas el derecho a recibir la diferencia entre el IPC estimado y el IPC real, sino que se remiten a la ley de presupuestos generales del Estado» $y$, con ello, vienen a presuponer una concesión al legislador de un determinado «margen de discrecionalidad a la hora de concretar la eventual actualización de la revalorización en función de las circunstancias económicas y sociales en cada momento existentes, todo ello con la finalidad de asegurar la suficiencia y solvencia del sistema de Seguridad Social». Esta jurisprudencia se repite después en otros fallos del Pleno del 2015 (SSTC 95/2015, de 14 de mayo, y $109 / 2015$, de 28 de mayo).

La decisión de mayor interés de este año en el marco de la teoría y organización del Estado, a nuestro juicio, probablemente sea la STC 93/2015 (Pleno), de 14 de mayo ${ }^{12}$. Son conocidos los problemas económicos que se han suscitado en la población española con motivo de la crisis económica. El boom inmobiliario antes de la crisis había llevado a una política bancaria muy laxa en cuanto a las concesiones de créditos hipotecarios. Cualquier trabajador con contrato aun de perfil inestable podía adquirir compromisos de hipoteca sin excesivas garantías. Al llegar la crisis, en torno a 2008, el empleo se desplomó y los bancos perdieron liquidez. El sector bancario recibió ayu-

12 Sobre el fallo, véase, Tejedor Bielsa (2015). 
das, primero del FROB (Fondo de Reestructuración Ordenada Bancaria), de unos 20000 millones de euros y entre 34000 a 41000 de la UE ${ }^{13}$. Muchos ciudadanos, en cambio, perdieron su vivienda e incluso algunos se vieron avocados al desahucio. En el Estado, la ayuda de los ciudadanos y familias se traspuso en el Real Decreto Ley 6/2012, de 9 de marzo, de medidas urgentes de protección de deudores hipotecarios sin recursos y la Ley 1/2013, de 14 de mayo, que regulan la dación en pago de la vivienda. La Junta de Andalucía lanzó como medida el Decreto-ley 6/2013, de 9 de abril, de medidas para asegurar el cumplimiento de la función social de la vivienda, que posibilitaba en ciertos casos la expropiación de viviendas vacías en el stock de entidades bancarias. Respecto a la posibilidad de uso de la figura del decreto ley en el marco autonómico, el Tribunal entiende que sí, si es una fuente normativa utilizable por la comunidad autónoma, aun cuando no está específicamente prevista por la Constitución cuando define la organización territorial del Estado en su título VIII. «Dada la caracterización abierta — nos dice el Pleno- del régimen autonómico y la función constitucional de los estatutos de autonomía, la imprevisión en el título VIII de la categoría del decreto ley no puede verse como una prohibición, sino como un espacio entregado a la libre configuración del legislador estatutario, a quien, al ordenar las instituciones de la comunidad autónoma, le cabrá optar por una separación más o menos rígida entre Legislativo y Ejecutivo, atribuyendo en su caso a este último la facultad de, en concretos supuestos, aprobar normas provisionales con rango de ley que adopten la forma de decreto ley autonómico». Ahora bien, por lo mismo, las facultades en este sentido del Ejecutivo autonómico se sujetan a los mismos límites impuestos al decreto-ley del art. 86.1 de la Constitución, a saber: «que se justifique para caso de extraordinaria y urgente necesidad, que no afecte a las materias más definidoras de nuestro sistema constitucional (ordenamiento de las instituciones básicas del Estado; derechos, deberes y libertades de los ciudadanos regulados en el título I; régimen de las comunidades autónomas; derecho electoral general, y otras materias reservadas a una ley formal específica) y que se disponga un control parlamentario posterior a fin de que el órgano legislativo conserve una influencia decisiva sobre los contenidos normativos que se integran definitivamente en el ordenamiento jurídico». Desde esta base, el Tribunal entiende que la cuestión de la expropiación de viviendas que hace la norma «más que delimitar un concreto sistema urbanístico o una determinada política de vivienda, se dirige a precisar el haz de facultades que integra este tipo de derecho de propiedad privada» (art. 33 de la Constitución). Y, en lo que a ello refiere, el Tribunal comprende que

13 Maroto Illera et al. (2012: 16-21). 
«es inconstitucional y nulo por contravenir uno de los límites materiales del decreto ley», por cuanto el precepto autonómico establece un contenido del derecho de propiedad de la vivienda, que afecta incluso su contenido esencial (art. 53.1), en el sentido del art. 86.1 CE, y por tanto entra a regular un ámbito que queda excluido del decreto ley y pretende delimitar un contenido esencial, para lo que ningún legislador es competente.

En materia de límites a los decretos leyes y falta de acreditación de presupuesto habilitante para aprobar con carácter urgente una de estas leyes especiales en su variante ómnibus, cabe destacar la STC 199/2015 (Pleno), de 24 de septiembre. Interesa el fallo, en particular, en cuanto vuelve sobre el tema de la delimitación precisa del objeto y la incidencia de este tipo de normas y sus posibilidades de uso por el Ejecutivo. A efectos de explicación diremos que, en efecto, la norma incluía regulaciones sobre materias tan dispares como, por ejemplo, comercio minorista y liberalización de horarios comerciales, cuestiones relativas a tasas de intercambio en operaciones de pago con tarjeta de débito y crédito, regulación de emanaciones de gases licuados del petróleo, aspectos relativos a la comercialización de bombonas de butano y propano, fomento de la empleabilidad y la ocupación juvenil, modificación parcial del IRPF y otros impuestos, daciones en pago y ejecuciones hipotecarias, aprobación de plazas para las diferentes escalas de las Fuerzas Armadas, cambio de denominación de la exposición conmemorativa de Picasso, y modificación del régimen de llevanza del Registro Civil por parte de los registradores de la propiedad y mercantiles. El Tribunal reconoce la pluralidad de contenido de lo que ha venido en denominarse «decreto-ley ómnibus», por la heterogeneidad y el alcance expansivo de las medidas que suelen incluir, circunstancia esta que debe otorgar también — según él— cierta singularidad al pronunciamiento de este Tribunal para perfilar y calibrar las causas de impugnación. Ahora bien, a juicio del Pleno, un contenido tan heterogéneo del decreto ley como el descrito no tiene presupone per se un cambio de su naturaleza como tal decreto ley, ni tiene por qué alterar su relación con las demás normas del ordenamiento, ni el sistema de fuentes establecido en la Constitución, por lo que cara a la evaluación de su constitucionalidad y validez cabe volver sobre la propia doctrina general del Tribunal sobre decretos leyes, que permite efectuar sobre la norma impugnada un juicio valorativo también sobre la base de la concurrencia o no del presupuesto habilitante y de respeto de sus requisitos en materia de límites materiales del decreto ley.

Otra resolución que ha tenido bastante eco ha sido la STC 270/2015 (Pleno), de 17 de diciembre, que determinaba la constitucionalidad de la reforma energética y el recorte de primas a las renovables, también dentro del tema de estudio de los límites a los decretos leyes y el principio de jerarquía normativa. Como introducción, cabe decir que el uso de energías renovables fue en su mo- 
mento muy bien recibido en España, por sus menores emanaciones y la nueva política medioambiental en la $\mathrm{UE}^{14}$, y recibió beneficios, subvenciones y un régimen jurídico favorable a las productoras. Ahora bien, con la llegada de la crisis, los costes de producción de la nueva energía llevaron a una política restrictiva, de reducción y recorte de ayudas e incentivos a los generadores de este tipo de electricidad, yendo cada vez a una minoración mayor hasta llegar al Decreto Ley 9/2013, de 12 de julio, por el que se adoptan medidas urgentes para garantizar la estabilidad financiera del sistema eléctrico. En lo que aquí interesa, el Consejo de Gobierno de la Comunidad Autónoma de la Región de Murcia interpuso un recurso de inconstitucionalidad por entender que la norma no se ajustaba al art. 86.1 de la Constitución, por no concurrir el presupuesto habilitante de la extraordinaria y urgente necesidad previsto en dicho precepto constitucional para poder utilizar la técnica del decreto ley. El Tribunal no lo entiende así y da una respuesta a ambas cuestiones desde una perspectiva que se complementa. Por un lado, respecto a la apreciación de urgencia, la justifica en «la evolución expansiva de los costes del sistema eléctrico, unida a las consecuencias de la crisis económica y a la necesidad de cumplimiento de los objetivos de déficit para el año 2014, que determinaban la necesidad de adopción de una serie de medidas dirigidas a garantizar la estabilidad financiera del sistema eléctrico, mediante una revisión de su marco regulatorio». A juicio del Pleno, ha sido pues, «la situación de crisis económica, que ha repercutido en una caída imprevista de la demanda de energía eléctrica, junto con el incremento general de costes, la que ha provocado un aumento imprevisto del déficit tarifario, lo que justifica la adopción de las medidas contempladas en la norma que se examina». En lo que respecta al examen del presupuesto habilitante de la extraordinaria y urgente necesidad, el Tribunal también apela a la problemática a la que debían hacer frente las medidas del Ejecutivo, cual era la desviación de los costes del sistema eléctrico provocado por diversos factores (sobrecoste de las primas del régimen especial, consignación de costes de los sistemas eléctricos extrapeninsulares e incremento del déficit por el descenso en la demanda de electricidad) y que, a su juicio, aparecían explicitados en la exposición de motivos y en el debate parlamentario de convalidación ${ }^{15}$.

\section{ESTRUCTURA TERRITORIAL DEL ESTADO}

Las SSTC 31 y 32/2015 (Pleno), de 25 de febrero, podrían perfectamente volver se a citar aquí. En relación con el primer fallo, ya hemos expuesto

14 Véase así Alenza García (2016).

15 Más sobre ello, Del Guayo Castiella (2016). 
brevemente cómo el art. 149.1.32 de la Constitución determina como competencia exclusiva del Estado la «autorización para la convocatoria de consultas populares por vía de referéndum». El Tribunal cierra esta disyuntiva remitiéndose a la literalidad de la Constitución y, en su caso, a la Ley Orgánica 2/1980, de 18 de enero, reguladora de las distintas modalidades de referéndum. Y, a su juicio, «no se regulan en esta Ley Orgánica otros supuestos de referéndum distintos de los contemplados en el texto constitucional, en particular, no se mencionan otras consultas de ámbito autonómico que las previstas en los arts. 151 y 152 de la Constitución" y los previstos para el caso de trámite de aprobación de estatutos de autonomía y de reformas de los mismos; aparte, su disposición adicional «excluye del ámbito de aplicación de la Ley a las consultas municipales, remitiendo su disciplina a la legislación básica de régimen local (art. 71 de la Ley 7/1985, de 2 de abril, Reguladora de las Bases del Régimen Local), ámbito sobre el que también se proyecta el art. 149.1.18 CE, que atribuye al Estado la competencia exclusiva en relación con las bases del régimen jurídico de las administraciones públicas». Y lo mismo se ratifica en la STC 32/2015, cuando el Pleno nos indica que cualquier consulta convocada al margen de estas reglas elementales, sin la preceptiva autorización estatal, como exige el art. 149.1.32 CE, y sin seguir los procedimientos y garantías constitucionalmente exigidos, vulnera las competencias del Estado en materia de referéndum, y cuando nos recuerda que este tipo de consultas solamente pueden ser organizadas bajo los parámetros establecidos por el legislador estatal, que es a quien la Constitución ha encomendado regular el proceso y las garantías electorales, de conformidad con los arts. 149.1.1, 23.1, 81.1, 92.3 y 149.1.32 de la Constitución.

La STC 46/2015 (Pleno), de 5 de marzo de 2015, resuelve, por otro lado, un recurso de inconstitucionalidad interpuesto por el Defensor del Pueblo contra determinados preceptos de la Ley del Parlamento de Cataluña 24/2009, de 23 diciembre, del Síndic de Greuges. La demanda del Defensor del Pueblo consideraba inconstitucional la parte del texto legal que atribuía al Síndic de Greuges facultades exclusivas de supervisión sobre la Administración Local y los organismos de ella dependientes, sin limitarlas a aquellas materias en las que el Estatuto de Autonomía atribuye competencias a la comunidad autónoma; en particular, por ejemplo, la norma atribuía al Síndic de Greuges la condición de "Autoridad para la Prevención de la Tortura y de Otros Tratos o Penas Crueles, Inhumanos o Degradantes». La base de actuación en la comunidad autónoma de este instituto viene en el art. 78 de la Ley Orgánica 6/2006, de 19 de julio, de Reforma del Estatuto de Autonomía de Cataluña, donde se recogen sus funciones y fines. El Tribunal no anula in toto la norma, sino que circunscribe la acción del Síndic dentro de los límites que determina el propio Estatuto y el art. 149 de la Constitución, a saber, como órgano con 
facultades de supervisión a tales efectos en espacios que sean titularidad de la Administración de la Generalitat y a la Administración Local de Cataluña.

La STC 57/2015 (Pleno), de 18 de marzo y la ya comentada STC 92/2015 (Pleno), de 14 de mayo, pueden ser también destacadas en este epígrafe. La STC 57/2015 devenía de un recurso de inconstitucionalidad también frente a la Ley del Parlamento de Cantabria 2/2004, de 27 de septiembre, del Plan de Ordenación del Litoral. El motivo de recurso, grosso modo, era que la norma autonómica incurría en infracción de la legislación básica ambiental dictada por el Estado al amparo de la competencia exclusiva que le atribuye el art. 149.1.23 CE, en particular, que el plan del litoral no se había sometido a evaluación de impacto ambiental. Estas resoluciones vienen a reforzar la posición de las competencias y funciones de las entidades municipales en materia de suelo y urbanismo frente a la siempre creciente voracidad del Ejecutivo y el legislador autonómico al respecto. En el caso de la STC 57/2015, se daba también la vicisitud de que el texto recurrido llegaba a determinar de algún modo el carácter superfluo de una calificación urbanística municipal en pro de la facultad del Ejecutivo autonómico para aprobar proyectos de suelo según los casos (art. 51.3 de la norma), y ello aun cuando la calificación puede ser competencia local. El Tribunal proscribe esta posibilidad genérica, en tanto habilitaba al Ejecutivo autonómico a «prescindir de la clasificación urbanística del suelo en el diseño y ejecución de sus políticas sectoriales con incidencia territorial», llevando un debilitamiento del principio de autonomía municipal y una quiebra injustificada del principio de autonomía.

Interesa aquí también señalar la STC 84/2015 (Pleno), de 30 de abril. La impugnación se dirigía a la Ley 8/2012, de 28 de diciembre, de medidas fiscales y administrativas de la Comunidad de Madrid que permitía al Servicio Madrileño de Salud a adjudicar contratos para la gestión del servicio público de asistencia sanitaria especializada en distintos hospitales privados de la Comunidad de Madrid. La aprobación de esta norma dio lugar a una importante movilización del sector de la sanidad en Madrid, que llevó por eslogan "Marea blanca», dado el color que tomaban las manifestaciones por acudir los convocados con la típica bata blanca de los médicos y profesionales de la medicina. Según su análisis, el Tribunal valida las posibilidades de regulación de la Comunidad de Madrid en este tema y, en su caso, de externalización o privatización de servicios. A su juicio, el legislador autonómico madrileño se había movido dentro de los límites definidos por la normativa estatal, en particular por el ya referido art. único de la Ley 15/1997, de 25 de abril, sobre habilitación de nuevas formas de gestión del Sistema Nacional de Salud, que vino en su día a reconocer ya la posibilidad de acudir a técnicas de gestión indirecta del servicio público de la sanidad. Aparte, indica que lo cierto es que la norma no contenía una habilitación in extenso cara a la externalización en 
favor de empresas privadas, sino que lo determinaba como «una posibilidad, pero no un imperativo", razón por la cual, en tanto vía alternativa, tenía cabida dentro del marco de la Ley 15/1997, de 25 de abril. Ahora bien, fuera de esto, el Tribunal si declara la inconstitucionalidad y nulidad de la cláusula de priorización de contratación de servicios en favor de determinados hospitales privados que hacia la norma impugnada. En este sentido, el Pleno entendía que la preferencia que otorgaba el precepto autonómico impugnado a las sociedades de profesionales, compuestas íntegra o mayoritariamente por profesionales del Servicio Madrileño de Salud, era contraria a la legislación básica del Estado en materia de contratos y concesiones administrativas (art. 149.1.18 de la Constitución).

Un número importante de fallos han ido dirigidos a estudiar los límites de las potestades tributarias de las comunidades autónomas, en particular el análisis de nulidad de los preceptos legales autonómicos que regulan el impuesto sobre los depósitos en las entidades de crédito (SSTC 30/2015 [Pleno], de 19 de febrero, 107, 108 y 111/2015 [Pleno], de 28 de mayo y 202/2015 [Pleno], de 24 de septiembre). Todos ellos devenidos de recurso de inconstitucionalidad del Ejecutivo y con resultado estimatorio por parte del Tribunal. Las razones para la declaración de invalidez de la norma autonómica obedecían, respectivamente, a distintos motivos, bien porque se daba duplicidad impositiva entre impuestos sobre depósitos bancarios de nivel estatal y autonómico, con vulneración del art. 6.2 de la Ley Orgánica 8/1980, de 22 de septiembre, de Financiación de las Comunidades Autónomas, bien porque se habían determinado tributos autonómicos por vía de decreto ley, cuando el estatuto de autonomía, en su caso, solo permite la creación de los mismos por ley de la asamblea legislativa de la comunidad autónoma. El Tribunal ha podido corregir así, en este sentido, la Ley de las Cortes Valencianas 5/2013, de 23 de diciembre, de medidas fiscales, el Decreto Ley de Cataluña 5/2012, de 18 de diciembre, del impuesto sobre los depósitos en las entidades de crédito, la Ley de la Junta General del Principado de Asturias 3/2012, de 28 de diciembre, de presupuestos generales para 2013 y la Ley del Parlamento de Cataluña 4/2014, de 4 de abril, del impuesto sobre depósitos en las entidades de crédito.

La STC 156/2015 (Pleno), de 9 de julio, también cabe aquí. El fallo deriva de un recurso de inconstitucionalidad interpuesto por el Consejo de Gobierno de la Junta de Andalucía contra distintos arts. del Real Decreto Ley 20/2012, de 13 de julio, de medidas para garantizar la estabilidad presupuestaria y de fomento de la competitividad y que redujo los días de libre disposición y por asuntos propios - los denominados «moscosos», en razón del ministro que los creó, Javier Moscoso, por Instrucción del Ministerio de la Presidencia de 21 de diciembre de 1983- al funcionariado público de seis a 
tres días al año. El Tribunal analiza si esta reducción respecto al funcionariado en general entra dentro de las competencias estatales y del art. 149.1. 13 y 18 de la Constitución. El Tribunal recuerda su jurisprudencia en esta materia, indicando cómo, a tenor de la distribución de competencias entre el Estado y la comunidad autónoma en materia de función pública, corresponde al Estado establecer las bases del régimen de derechos y deberes de los funcionarios públicos y a la comunidad autónoma la competencia de desarrollo legislativo y ejecución, de acuerdo con aquella legislación básica, en relación con la función pública autonómica y local. «La duración de tales permisos o licencias de los funcionarios públicos — nos dice el Pleno- entra dentro de lo básico, correspondiendo al Estado su fijación, en la medida en que, a través de las bases, se establece un régimen común, tanto de los diferentes conceptos de ausencia temporal justificada al puesto de trabajo, como de la duración de aquellos. Con tal planteamiento no se persigue otro objetivo que lograr una mínima y fundamental homogeneidad en este aspecto sustancial del régimen funcionarial que es el de los permisos y vacaciones, sin que tal delimitación impida a las comunidades autónomas el margen de actuación necesario para el desarrollo y ejecución de dichas bases». En definitiva, la posibilidad de recorte de días libres por el Gobierno halla su fundamento en la competencia del Estado sobre las bases del régimen de derechos y deberes de los funcionarios públicos (art. 149.1.18 CE) y posibilita un margen de desarrollo a las comunidades autónomas. Luego, además, el Tribunal incluso valida la forma normativa a través de la cual se había operado la reforma, a saber, por medio de real decreto ley. En términos generales, el Pleno entiende cubiertos los requisitos del art. 86.1 de la Constitución, dando por buenas las razones que el Ejecutivo da en la exposición de motivos para la utilización de este instrumento legal, a saber, entre otros, la necesidad de adoptar, por un lado, medidas extraordinarias dirigidas a racionalizar y reducir el gasto de personal de las administraciones públicas y a incrementar la eficiencia de su gestión, y, por otro, de reducción del déficit público sin menoscabar la prestación de los servicios públicos esenciales.

La Ley 2/2013, de 29 de mayo, de protección y uso sostenible del litoral y de modificación de la Ley 22/1988, de 28 de julio, de costas, ha sido corregida por el Tribunal Constitucional en su STC 233/2015 (Pleno), de 5 de noviembre. Para empezar, un precepto de esta ley establecía una determinación singular del dominio público marítimo-terrestre para la isla de Formentera, en violación frontal con el art. 132 de la Constitución que determina el dominio marítimo-terrestre de forma general, sin regímenes especiales. El Tribunal no da por suficientemente explicadas cuáles son las razones que empujan a la reducción de la superficie de dominio y de su protección, a diferencia del resto de las Islas Baleares y, consecuentemente, anula el precepto. Tampoco legitima el cambio de régimen de dominio público o su reducción cuando una 
determinada zona sea inundable por vía artificial para distintos fines, a saber, cuando - como establecía art. 1.2 de la Ley 2/2013 - se trate de «terrenos que sean inundados artificial y controladamente, como consecuencia de obras o instalaciones realizadas al efecto». A juicio del Tribunal, «el legislador dispone de margen de configuración para decidir acerca del régimen jurídico de los terrenos que, no perteneciendo a la ribera del mar, hubieran sido inundados mediante técnicas artificiales y controladas [...], pero procede, asimismo, afirmar, contrario sensu, que la pretensión de excluir porciones del dominio público natural en atención a su transformación artificial y al tipo de explotación resulta constitucionalmente inadmisible», por cuanto «la naturaleza demanial de estas categorías de bienes no es disponible para el legislador, puesto que está determinada directamente por el art. 132.2 de la Constitución». En cambio, el Tribunal no reconoce infracción en materia competencial sobre la base de que la norma supusiera una vulneración de las competencias autonómicas en materia de ordenación territorial y urbanística. Reiterando su jurisprudencia sobre el art. 149.1. 23 de la Constitución, el Tribunal repite el ejercicio estatal de esta competencia exclusiva, ya que así se garantiza que las limitaciones y servidumbres que establecen las leyes no tengan una proyección desigual sobre las facultades de los propietarios según las diversas situaciones urbanísticas de los terrenos e inmuebles de su titularidad. A efectos de justificar la competencia estatal, el Tribunal trae a colación, además, la STC 5/2015 (Pleno), de 22 de enero, donde declara la inconstitucionalidad de parte de la Ley de la Comunidad Autónoma de Canarias 7/2009, de 6 de mayo, de modificación del Texto Refundido de las Leyes de Ordenación del Territorio de Canarias y de Espacios Naturales de Canarias, y donde volvía también sobre el hecho de que en esta materia «el Estado ejerce una competencia propia, ex art. 149.1.23 de la Constitución y, de forma conexa, ex art. 149.1.1, para establecer servidumbres y limitaciones en los terrenos colindantes con el dominio público marítimo-terrestre - $\mathrm{y}$, entre ellas, la servidumbre de protección- a los efectos de garantizar la protección y defensa de sus condiciones medioambientales».

\section{ORGANIZACIÓN DE LOS PODERES PÚBLICOS}

En la crónica de 2014, ya pudimos ver brevemente la STC 197/2014 (Pleno), de 4 diciembre, que confirmaba la constitucionalidad de la Ley Orgánica 2/2014 de Reforma del Estatuto de Autonomía de Castilla-La Mancha de reducción de diputados integrantes de las Cortes de la Comunidad Autónoma. Ya entonces decíamos que a ojos del Tribunal, la autonomía política de la comunidad autónoma y su facultad de legislar en los ámbitos de su competencia presume también la capacidad de variar la composición y reducción del número de miembros de la asamblea autonómica propia, más cuando la 
Constitución, a estos efectos, realmente, no fija pauta expresa alguna sobre el número de integrantes del respectivo órgano legislativo; al contrario, casi puede decirse que su determinación es una cuestión que entra dentro de los puntos que han de definir los respectivos estatutos de autonomía y de las normas autonómicas que, en su caso, complementen y desarrollen tales previsiones estatutarias ${ }^{16}$. Pues bien, con motivo de otro recurso de inconstitucionalidad interpuesto desde el Senado contra otra norma - la Ley 4/2014, de 21 de julio, de Reforma de la Ley 5/1986, de 23 de diciembre, Electoral de Castilla-La Mancha-, el Tribunal ha vuelto a tratar este tema, ahora en la STC 15/2015 (Pleno), de 5 de febrero. El Pleno, para justificar la validez de la ley impugnada, vuelve sobre aquella sentencia y también sobre alguna otra más vieja, como, por ejemplo, la STC 45/1992, de 2 de abril, insistiendo en que "compete al legislador determinar el número de escaños asignados a cada circunscripción o condicionar su determinación; decisión esta que no debe hacerse en modo tal que se impida de iure toda posible proporcionalidad — cuando la Constitución la exija - en el procedimiento de conversión de votos en escaños». A juicio del Pleno, «el sistema electoral para la integración de las Cortes de la Comunidad Autónoma no ha perdido por obra de la ley impugnada, en definitiva, su capacidad para reflejar, según decida el cuerpo electoral, las principales opciones políticas existentes» $y$, por lo tanto, como en el caso de la STC 197/2014, procede a ratificar la no transgresión del mandato constitucional de proporcionalidad.

\section{DERECHOS FUNDAMENTALES}

\subsection{Derecho / principio de igualdad}

En primer lugar, reseñar aquí la STC 1/2015 (Sala Segunda), de 19 de enero. Se trata de una resolución de un recurso de amparo, interpuesto por el portavoz de un grupo parlamentario en la Asamblea de Madrid contra distintos acuerdos de la Mesa de la Asamblea Legislativa que habían inadmitido a trámite solicitudes de comparecencia, peticiones de trámite de preguntas de respuesta oral en Pleno e incluso la presentación de una proposición no de ley, lo que dificultaba la función del grupo a su labor de control en la cámara y de acción parlamentaria. El demandante de amparo considera que los acuerdos impugnados vulneran el derecho de acceder en condiciones de igualdad a las

16 OEHLING DE LOS REYES, A. (2015), Crónica de la jurisprudencia constitucional española en el año 2014, Anuario Iberoamericano de Justicia Constitucional, 18, CEPC, Madrid, págs.553-554. 
funciones y cargos públicos según lo dispuesto en el art. 23.2, en relación con el derecho de los ciudadanos a participar en los asuntos públicos a través de sus representantes, previsto en el art. 23.1 de la Constitución. Respecto a la restricción de la función de control político, el Tribunal — citando jurisprudencia anterior - entiende que "los acuerdos impugnados, al no haber admitido a trámite las preguntas formuladas, habían cercenado indebidamente el derecho del recurrente a ejercer, sin traba ilegítima alguna, las funciones que el Reglamento de la Cámara le confiere». Aparte, la Sala, resalta cómo «la facultad de formular preguntas de respuesta oral ante el Pleno pertenece al núcleo de la función representativa parlamentaria, pues la participación en el ejercicio de la función de controlar la acción del Consejo de Gobierno y de su presidente y el desempeño de los derechos y facultades que la acompañan, constituyen manifestaciones constitucionalmente relevantes del ius in officium del representante». Respecto a la limitación de presentación de proposiciones no de ley, entiende que ni en el Estatuto de Autonomía de la Comunidad de Madrid, ni en el Reglamento de la Cámara, de 30 de enero de 1997, había ni hay disposición alguna que posibilite rechazar a limine el trámite de proposiciones no de ley en función del contenido material de las mismas, razón por la cual se otorga el amparo.

La STC 19/2015, (Sala Primera), de 16 de febrero, versa también sobre un amparo por lesión de los mismos derechos fundamentales, por inadmisión por la Mesa del Parlamento de Cataluña del trámite de una iniciativa legislativa popular, suscrita por 68000 firmas, en la que la ciudadanía solicitaba que se volviera en Cataluña al sistema de horario escolar anterior a 2011, sin reducción de la sexta hora del diario de los colegios públicos de la comunidad autónoma. Aquí la Sala, también reconoce la afección de los derechos fundamentales alegados, por cuanto entiende que el rechazo de la iniciativa había impedido que se hubiera podido llegar a perfeccionarse esta iniciativa y, en su caso, que los ciudadanos hubieran podido al menos conocer de primera mano lo que sus representantes pensaban sobre la materia objeto de la iniciativa, así de hasta qué punto estos se separan o no de lo manifestado sobre este tema en sus respectivos programas electorales.

La STC (Sala Primera) 77/2015, de 27 de abril, puede también reseñarse aquí. Resulta que unos padres de tres hijos habían adquirido una vivienda, solicitando después devolución de cantidad correspondiente a la subvención de la comunidad autónoma por adquisición de vivienda habitual por familia numerosa. Dicha solicitud sería desestimada por la resolución de la Dirección General de Tributos de la Consejería de Economía y Hacienda de la Comunidad de Madrid por entender que los solicitantes, en el momento del devengo del tributo, carecían del título acreditativo de la condición de familia numerosa. Contra dicha resolución reclamaron los padres por vía de recla- 
mación económico-administrativa, donde sí fue reconocido el reembolso, si bien luego - por presentación de recurso contencioso-administrativo por la representación de la Comunidad de Madrid- les volvería a ser negada. Así las cosas, la parte acudiría en amparo ante el Tribunal, alegando la vulneración del derecho a la igualdad (art. 14 de la Constitución) en relación con el principio de protección social, económica y jurídica de la familia (art. 39.1). A juicio de la actora, las resoluciones judiciales en vía ordinaria introducían no sólo una diferencia entre situaciones que pueden considerarse iguales, sin que se exista una justificación objetiva y razonable para ello, sino que, además, las consecuencias jurídicas que derivaban del trato desigual resultaban desproporcionadas a la finalidad perseguida. El Tribunal llama la atención al órgano judicial por no optar en la solución del caso por la interpretación más favorable al derecho fundamental. En efecto, a juicio de la Sala, no cabe duda de que las resoluciones judiciales impugnadas habían optado, respectivamente, por la interpretación más formalista y menos conforme con la noción de igualdad de todos (en este caso, de las familias numerosas) en el cumplimiento del deber de contribuir a las cargas públicas (arts.14 y 31.1 de la Constitución), pues a la fecha del devengo del tributo (momento de la adquisición de la vivienda) los recurrentes ya tenían la condición de familia numerosa, acreditada con el libro de familia, aunque no por el de familia numerosa. El Tribunal otorga el amparo y reconoce, en ejecución del fallo, el reconocimiento del derecho a la aplicación del tipo de gravamen previsto para las familias numerosas.

\subsection{Libertad ideológica y religiosa}

Una de las resoluciones más esperadas de este año posiblemente haya sido la STC 145/2015 (Pleno), de 25 de junio. Desde hace tiempo se planteaba la operatividad del derecho a la objeción de conciencia de los profesionales farmacéuticos en orden a la comercialización y venta de la llamada "píldora del día después» o "píldora poscoital», por motivos de conciencia o creencias. La Ley $29 / 2006$, de 20 de julio, de garantías y uso racional de los medicamentos y productos sanitarios establecía, de algún modo, la obligatoriedad de las farmacias a dispensar los medicamentos que les solicitaran los particulares o le vinieran prescritos por el Sistema Nacional de Salud (art. 84.3), considerando infracción grave el negarse a dispensar medicamentos «sin causa justificada» (art. 101.6). La cuestión estaba por tanto en si la no dispensa por actuar bajo los dictados de la propia conciencia se podía comprender, a estos efectos, como "causa justificada». La Sala de lo Contencioso-Administrativo del TSJ de Andalucía, en su sentencia de 30 de julio de 2002, confirmada por el Tribunal Supremo (STS de 23 de abril de 2005) en este sentido, había apuntado que la objeción de conciencia formaba parte de la libertad ideológica del art. 16.1 de la Constitución y, 
asimismo, que estaba muy vinculada al concepto de dignidad de la persona y el libre desarrollo de la personalidad del art. 10.1, lo que presupondría una reserva de acción de la garantía de la objeción de conciencia para el caso de los profesionales sanitarios con facultades de prescripción y dispensa de medicamentos ${ }^{17}$. Ahora bien, ni el TSJ de Andalucía ni el Tribunal Supremo venían en estos fallos a declarar claramente el reconocimiento del derecho a la objeción de conciencia del farmacéutico en estos $\operatorname{casos}^{18}$. Así se habían sucedido algunas sanciones de farmacias que ejercían su acción de desobediencia civil y se habían negado a dispensar este tipo de pastillas. La STC 145/2015 deviene, precisamente, de una de estas sanciones administrativas. El Tribunal Constitucional, por fin, avala ya definitivamente, sobre la base de la libertad ideológica, religiosa y de objeción de conciencia, el derecho del farmacéutico a no dispensar la «píldora del día siguiente». Ello, a juicio del Pleno, no supondría una violación de la libertad sexual de la mujer. Ahora bien, no ampara la negativa — sujeta sobre los mismos derechos fundamentales - a no vender otro tipo de medidas profilácticas, como los preservativos. Para el Tribunal, si bien la píldora, en su caso, puede dar lugar a "efectos abortivos», lo cual habilitaría efectivamente al farmacéutico — como en el caso de los cirujanos y médicos - a plantearse desde su conciencia la justificación de sus actos, no ocurriría lo mismo con la renuencia a dispensar preservativos, pues estos no tienen el mismo resultado contraceptivo. De ahí que el Tribunal, en lo que se refiere a esto último, dice que la objeción de conciencia no permite no tener ex profeso existencias en la farmacia. En consecuencia, el otorgamiento del amparo presupone el reconocimiento del derecho fundamental vulnerado, "pero exclusivamente en lo que concierne a la falta de existencias mínimas del medicamento con el principio activo levonorgestrel 0’750 mg», no en lo que «se refiere a la infracción grave que se le imputa por negarse a disponer de (y por ello a dispensar) preservativos en la oficina de farmacia de la que es cotitular ${ }^{19}$.

\subsection{Derechos de libertad personal}

En materia de vulneración del derecho a la libertad personal e inadmisión de una petición de habeas corpus por razones de fondo, encontramos la

17 Véase Alenda Salinas (2008).

18 Id.

19 Sobre ello, críticamente, Tajadura Tejada (2015), que se alinea con el voto particular discrepante de la magistrada Adela Asua Batarrita, y donde afirma que en este fallo lo que se hace el Tribunal Constitucional es decir que «la conciencia personal prevalece sobre el cumplimiento de las leyes». 
STC 42/2015 (Sala Segunda), de 2 de marzo. Ya en la crónica del año pasado pudimos observar las SSTC 12/2014, de 27 de enero, y 21/2014, de 10 de febrero, donde se aceptaba la petición de amparo por violación del art. 17.4 de la Constitución por inadmisiones a limine de peticiones de habeas corpus que habían estado fundamentadas con fórmulas en extremo parcas como «que no he hecho nada para estar detenido» o que "no he cometido hecho delictivo alguno» ${ }^{20}$. En la STC 42/2015, la solicitud de amparo devenía de un caso en el que el encartado, estando detenido, había solicitado la incoación del procedimiento de habeas corpus, interesando, en consecuencia, su puesta a disposición de la autoridad judicial, sobre la razón de que, a su juicio, la situación de detención no estaba justificada, y decía: «Se debe por un dinero que me prestaron y mi madre me lo pide ya hace días y no puedo dárselo; porque tengo una hija que lo necesita». El Juzgado, sin oír previamente al detenido, acordó denegar a limine la incoación del referido procedimiento, razonando que el caso planteado por el detenido «no puede considerarse encuadrado en ninguno de los apartados del art. 1 de la Ley Orgánica 6/1984, de 24 de mayo, reguladora del procedimiento de habeas corpus, por lo que, conforme establece su art. 6, debe considerarse improcedente la petición efectuada». El Tribunal Constitucional entiende lesionado, en efecto, el derecho fundamental. «Si bien — dice la Sala - la finalidad del procedimiento de habeas corpus no es pronunciarse sobre la inocencia o culpabilidad del detenido, sí que constituye uno de sus objetos analizar el cumplimiento de los presupuestos de la legalidad de una detención preventiva, como es que existan indicios de haberse cometido un delito del que el detenido pueda ser responsable; y esto es lo que se solicitó por el detenido. Lo que se instaba en su escrito de solicitud de habeas corpus no podía entenderse como un pronunciamiento sobre la eventual responsabilidad penal del detenido, sino sobre si concurrían los presupuestos legales habilitantes para la detención gubernativa, cuyo examen oyendo al detenido mediante la sustanciación del habeas corpus, es competencia del juez de instrucción del lugar en que se encuentra aquel».

ATC 73/2015 (Sección Segunda), de 21 de abril, puede ser también aquí brevemente comentada. El letrado de un detenido había solicitado poder acceder al atestado policial con carácter previo a que tuviera lugar la declaración policial, cosa a la que no se accedió, razón por la cual presentó solicitud de habeas corpus ante el Juzgado. Según el abogado, la negativa de acceso previo al atestado incumplía el art. 7 de la Directiva 2012/13/UE, que posibilita el acceso a los materiales que obran en el expediente a fin de verificar la legalidad de la detención; es por esto que solicitaba la estimación del habeas corpus por

20 Oehling de los Reyes, A. (2015: 556-557). 
vulneración del art. 1 de la Ley Orgánica 6/1984, de 24 de mayo. En tanto el Juzgado de Primera Instancia e Instrucción, por auto, inadmitiría la solicitud de habeas corpus, el letrado en representación del encartado interpuso recurso de amparo por vulneración del derecho a la asistencia letrada al detenido como garantía del derecho a la libertad (arts.17.3 y 17 de la Constitución), así como del derecho de defensa en relación con el derecho a la tutela judicial efectiva (arts. 24.2 y 24.1), por no haber tenido acceso al atestado. Mediante Providencia de 16 de febrero de 2015, la Sección Segunda del Tribunal Constitucional, acordaría inadmitir a trámite el recurso de amparo toda vez que no se habían agotado debidamente todos los medios de impugnación dentro de la vía judicial (arts. 50.1 a y 44.1 a de la LOTC. Tras queja frente a la Providencia, por recurso de súplica ante la misma Sección, esta vuelve sobre el tema. El Tribunal recuerda el sentido final del incidente de nulidad de actuaciones del art. 241 de la LOPJ: «Ciertamente — dice la Sección-, el incidente de nulidad de actuaciones, a partir de la reforma introducida en el art. 241 de la Ley Orgánica del Poder Judicial (LOPJ) por la Ley Orgánica 6/2007, de 24 de mayo, es el instrumento idóneo para obtener ante la jurisdicción ordinaria la reparación de aquellas vulneraciones de los derechos fundamentales referidos en el art. 53.2 CE, que se entiendan cometidas en resolución judicial frente a la que la ley procesal no permita ningún recurso. Así, este precepto exige para la admisibilidad del incidente que la vulneración de que se trate no haya podido denunciarse antes de recaer resolución que ponga fin al proceso y que dicha resolución no sea susceptible de recurso ordinario ni extraordinario». Sobre la base de su propia doctrina, la Sección desestima la súplica, pues entiende que «la falta de agotamiento alcanza también a la queja relativa a la no entrega del atestado por los agentes de policía, pues de haberse interpuesto aquel incidente de nulidad y de haber sido estimado por el juez, este podría haber reparado la eventual vulneración derivada de la inadmisión a limine del procedimiento de habeas corpus».

Interesa referenciar en este punto la STC 182/2015 (Sala Segunda), de 7 de septiembre. El 11 de junio de 2014 había ingresado un sujeto, a causa de un brote psicótico, en una unidad psiquiátrica y así se comunicó a los Juzgados de Primera Instancia de las Palmas, si bien no el mismo día 11 - como debía haber sido - sino el día 13 de junio de 2014, justo el día, además, en que ya el internado no quería proseguir su internamiento. Aparte, por retardo en reparto de asuntos, no sería hasta el 16 de junio cuando la comunicación de ingreso tuvo entrada en el Juzgado, siendo ese mismo día 16 cuando el órgano judicial competente acordó la incoación de internamiento no voluntario. El fiscal se oponía a dicha decisión de internamiento involuntario, en primer lugar porque entendía que el centro psiquiátrico había incumplido la obligación de comunicar el ingreso a la autoridad judicial dentro del plazo de 
24 horas; en segundo término porque consideraba que había transcurrido el plazo máximo de 72 horas previsto legalmente para la ratificación judicial del internamiento urgente. Por auto, el órgano judicial ratificaba el internamiento $\mathrm{y}$, asimismo, resolvía que se informara con periodicidad semestral sobre el estado y evolución de la paciente ingresada. Así las cosas, el fiscal interpondría recurso de apelación, que sería inadmitido por la Audiencia Provincial de Las Palmas, por entender que «la cuestión a decidir es si el plazo de 72 horas empieza a contar desde que el centro médico comunica el internamiento al Decanato, o desde que se reparte el asunto al tribunal competente para resolverlo». A efectos de analizar dicha afirmación, el fiscal, finalmente, interpone demanda de amparo frente a las resoluciones judiciales que, a su entender, son contrarias al derecho a la libertad personal del art. 17.1 de la Constitución. El Tribunal, al final, lo entiende en los mismo términos del fiscal. Sobre la base de conocidas decisiones en la materia (SSTC 37/1996, de 11 de marzo, 180/2011, de 21 de noviembre), nos viene a decir que una de las principales garantías de este marco regulador del internamiento urgente lo constituye el límite temporal del que dispone el juez para resolver, que tiene base tanto en los arts.17.1 y 2, en lo que se refiere a la observancia del cumplimiento de la Constitución y la ley en materia de privación de libertad, y de plazo de duración de la medida. En este contexto, el plazo ha de considerarse improrrogable y, por tanto, «no puede mantenerse el confinamiento de la persona si a su expiración no se ha ratificado la medida, ni cabe aducir dificultades logísticas o excesiva carga de trabajo del órgano judicial para justificar su demora, ni puede considerarse convalidado el incumplimiento porque más tarde se dicte el auto y este resulte confirmatorio». Consecuentemente, la Sala, reconoce la lesión de los derechos fundamentales alegados y determina la nulidad de las resoluciones en vía ordinaria.

La STC 226/2015 (Sala Segunda), de 2 de noviembre, versa sobre una petición de amparo frente a las resoluciones previas en vía ordinaria que habían denegado su petición de solicitud de indulto parcial. El Tribunal no entra a analizar la violación del derecho a la libertad personal. «Debe descartarse -indica la Sala Segunda-, en primer lugar, que estemos ante una lesión del derecho fundamental a la libertad establecido en el art. 17 de la Constitución. Como este Tribunal ha tenido la oportunidad de señalar en repetidas ocasiones, la denegación de un beneficio penitenciario no puede suponer, en sentido propio, una lesión del derecho fundamental a la libertad consagrado en el art. 17.2 de la Constitución [...], pues es la sentencia firme condenatoria la que constituye título legítimo de privación de ese derecho fundamental (por todas, STC 79/1998, de 1 de abril). No cabe, pues, acudir, para examinar la queja formulada, al canon de proporcionalidad reservado a la vulneración del derecho fundamental sustantivo». 


\subsection{Intimidad}

La STC 18/2015 (Sala Segunda), de 16 de febrero, resolvía una demanda de amparo, devenida de vía ordinaria, contra determinados entes privados televisivos y productores - realizadores de programas de TV como Aqui hay tomate, TNT y Salsa rosa-, por vulneración de los derechos a la intimidad y a la propia imagen, ambos regulados en el art. 18.1 de la Constitución. Se daba la circunstancia de que se habían emitidos imágenes captadas de forma espuria y sin consentimiento. Aparte, en el «suplico» de sus demandas anteriores y en amparo, la demandante interesaba, además de la condena de los demandados por la vulneración de los derechos fundamentales, a que se fijara una indemnización de 100000 a cargo de los demandados. A efectos de resolución de la disyuntiva, el Tribunal dice: «En el presente caso, como ya se ha indicado, las escenas divulgadas versan sobre aspectos relativos a la vida privada del demandante, de manera que la invasión no consentida de ese ámbito reservado cercena la facultad de exclusión que aquél ostenta frente a una publicidad no querida [...]. El hecho de que las imágenes se obtuvieran en lugares de acceso público o la relación afectiva fuera ya conocida o, incluso, que el interesado hubiera podido favorecer la publicidad de ciertos aspectos de su vida privada, no impiden, en sí mismo considerados, apreciar la intromisión en el derecho a la intimidad personal». Más adelante, la Sala añade: «Además, el contenido de la información transmitida a través de las imágenes y comentarios efectuados en los espacios televisivos carece del interés general o relevancia pública que, de acuerdo a la doctrina asentada por este Tribunal, merece un valor preferente por contribuir a la formación de la opinión pública y asegurar una información libre en el seno de una sociedad democrática». En definitiva, ratifica la lesión del derecho a la intimidad personal del art. 18.1 de la Constitución. Y respecto a la indemnización, determina la procedencia de retroacción de actuaciones para que, "partiendo de la constatación del derecho a la intimidad de la parte recurrente (y, en el presente caso, también del derecho a la propia imagen) se resuelva por el Tribunal Supremo sobre la determinación de la indemnización que, en su caso, corresponda».

La STC 54/2015 (Sala Segunda), de 16 de marzo, versa sobre el derecho a la inviolabilidad del domicilio del art. 18.2 de la Constitución y al secreto de las comunicaciones del 18.3. El origen de la causa estaba en un procedimiento de inspección de la Hacienda Tributaria de Navarra por la que se iniciaron las actuaciones de comprobación e investigación de las declaraciones tributarias de la entidad mercantil recurrente y, a efectos de hilvanación del procedimiento administrativo económico sancionador, se tuvieron en cuenta los documentos y datos obtenidos por la entrada en el 
domicilio social de la recurrente, que se había llevado a cabo previamente por la Policía Foral de Navarra, un colaborador experto en informática y bajo permiso de los socios administradores, que permitieron el registro, el acceso a los ordenadores de la empresa y la copia de los discos duros; ahora bien - $-\mathrm{y}$ este es un detalle a tener en cuenta-, sin que constara en autos que los socios fueran informados de su derecho a oponerse a la entrada y registro. Frente a las sanciones, los afectados interpusieron recurso contencioso-administrativo ante Juzgado de lo Contencioso-Administrativo, con resultado desestimatorio, rechazando que se hubiera producido vulneración de derechos fundamentales. Luego interpuso recurso de apelación contra la citada resolución, que fue admitida por la Sala de lo Contencioso-Administrativo del TSJ de Navarra. EL TSJ determinaría la ilicitud de la diligencia en un apartado muy clarito que, a la postre hará suyo con otras palabras el Tribunal Constitucional. A juicio del TSJ: «En el presente caso, son hechos no discutidos que los funcionarios actuantes acudieron al domicilio social de Chatarras Iruña acompañados de un agente de la Policía Foral y portando una autorización administrativa que (se entendía) les habilitaba para ello, autorización que no fue necesario exhibir puesto que el acceso y posterior registro les fue facilitado por los socios administradores habilitados para ello por ostentar la representación legal de la sociedad. A ninguno de estos informaron aquellos del derecho que les asistía a oponerse a la entrada [...]. El juzgado ha estimado que, dada la actitud de los responsables de la empresa, no se incurrió en irregularidad alguna al procederse en la forma expuesta, conclusión que no podemos compartir por contraria a la doctrina establecida con valor de jurisprudencia [...], toda vez que el consentimiento no fue prestado previa información del derecho al que acabamos de referirnos, única forma válida que excusa la necesidad de la autorización judicial, siendo por ende irrelevantes cuantas consideraciones se hacen por la Administración en torno al alcance de la actitud mostrada por los representantes de la empresa que, en su opinión, relevaría a los inspectores actuantes de mostrar la autorización administrativa y de solicitar la judicial». El Tribunal termina por seguir esta visión y entender la violación del 18.2 de la Constitución y, por extensión, del 18.3 en relación con el secreto de las comunicaciones. En efecto, «la apreciación de esta lesión del art. 18.2 hace innecesario el examen de la alegada vulneración del secreto de las comunicaciones del art. 18.3 respecto de los datos obtenidos por la entrega de las facturas telefónicas de la sociedad recurrente, puesto que esta actuación trae causa de la entrada, donde se tomaron los datos obrantes en un archivo informático que pretendían corroborarse por la inspección, de manera que esta diligencia derivada resulta viciada por su conexión con la prueba obtenida con vulneración del derecho a la inviolabilidad del domicilio». 


\subsection{Libertad de expresión}

La STC 65/2015 (Sala Primera), de 13 de abril, versa sobre una petición de amparo solicitada por los portavoces de una asociación ecologista que habían sido condenados en vía ordinaria por publicar, en la típica sección "Cartas al Director» de un rotativo, un escrito donde se ponía en entredicho de forma ciertamente ácida la profesionalidad de una magistrado-juez del Juzgado de lo Contencioso Administrativo de Teruel, como crítica a su labor en un pleito anterior. Los solicitantes pedían la primacía de los derechos a la libertad de expresión y a la libertad de información del art. 20 de la Constitución y la declaración de nulidad de las sentencias condenatorias precedentes. El Tribunal no accede a la concesión de amparo. En efecto, a su juicio, «las resoluciones judiciales son plenamente susceptibles de crítica por la ciudadanía, pues en nuestra democracia pluralista la jurisdicción se ejerce no sólo en el seno del debate procesal, sino también ante el foro de la opinión pública libre. Pero lo que la Constitución no protege es una censura a esas resoluciones o a sus autores que parta exclusivamente, como aquí era el caso, ya de la reprobación ad personam, sin razón atendible, de quienes las dictaron, ya de premisas argumentales (la aducida incorrección de la pericia, sobre todo) que no consienten, en manera alguna, concluir en reproche tan severo como el de parcialidad».

También interesa referir aquí brevemente la STC 177/2015 (Pleno), de 22 de julio, igualmente, sobre límites al derecho del art. 20 de la Constitución. Lógicamente, si, como en el caso anterior, una crítica ácida no se entiende que tenga cabida en la Constitución, menos aún una provocación más dura, realizada en manifestación en vía pública, con intención de vejar y, más allá, de dejar claro el odio y el aborrecimiento absoluto hacia alguien e incluso manifestar sin tapujos su deseo de desaparición física de personales de relevancia pública. El Tribunal Constitucional analiza si el ejercicio de un derecho legítimo, cual es la libertad de crítica, puede, en su caso, pervertirse en su realización por el sujeto, en tanto estimula «desencadenar un reflejo emocional de hostilidad, incitando y promoviendo el odio y la intolerancia incompatibles con el sistema de valores de la democracia». "Cuando — dice de forma muy clara el Pleno- una idea u opinión se manifiesta, como en el caso enjuiciado, mediante la destrucción de elementos con un valor simbólico, la conducta ha de ser examinada con arreglo a un canon de enjuiciamiento particularmente atento a las concretas circunstancias del caso. Un acto de destrucción puede sugerir una acción violenta y, en consecuencia, ser susceptible de albergar mensajes que no merecen protección constitucional. Pues, como es obvio, no es jurídicamente indiferente manifestar la protesta o el sentimiento crítico utilizando medios o instrumentos inocuos para la seguridad y dignidad de las 
personas, que hacerlo incitando a la violencia o al menosprecio de las personas que integran la institución simbolizada o sirviéndose del lenguaje del odio ${ }^{21}$.

\subsection{Tutela judicial efectiva}

En materia de tutela judicial y acceso a recurso hay que destacar muy especialmente la STC 7/2015 (Pleno), de 22 de enero. En 2008 la demandante había sido sancionada en vía administrativa, razón por la cual interpuso recurso contencioso-administrativo contra la resolución sancionatoria del Tribunal Económico-Administrativo Central. La Sala de lo Contencioso-Administrativo de la Audiencia Nacional desestimó, en lo que aquí interesa, el recurso. En segunda instancia acudió, en casación, a la Sala de lo Contencioso-Administrativo del Tribunal Supremo. La parte advirtió por escrito ante la Audiencia Nacional que había tenido conocimiento del Auto dictado por la Sala de lo Contencioso-Administrativo del Tribunal Supremo, de 10 de febrero de 2011, por el que el Tribunal Supremo modificaba su doctrina en cuanto a los requisitos exigibles en el escrito de preparación del recurso de casación contra sentencias dictadas por la Audiencia Nacional, añadiendo el de expresar las concretas infracciones normativas o jurisprudenciales que se consideran cometidas, razón por la cual procedía a adecuar su escrito a las nuevas exigencias del Supremo. Ahora bien, esto no pareció estar del todo claro - es decir, que la demanda se había configurado conforme a los nuevos requisitos_-, ya que, después, por auto de la Sala Tercera del Tribunal Supremo, se declaró la inadmisión de petición de casación. El Tribunal Supremo se justificaba en su inadmisión remitiéndose a dicho ATS de 10 de febrero de 2011, diciendo que «no habiéndose citado ni en el escrito de preparación del recurso formalizado por la sociedad recurrente ni en el formalizado por el abogado del Estado las infracciones normativas o jurisprudenciales que iban a desarrollarse en el escrito de interposición, procedía la inadmisión de ambos recursos de casación». Ante esta situación, la recurrente, interpone petición de amparo, por entender lesionados su derecho a la tutela judicial efectiva en su vertiente de acceso a los recursos, porque el auto, a su entender, se fundaba en un requisito de admisibilidad no exigido por la ley y porque la exigencia de anticipar en el escrito de preparación del recurso de casación los concretos preceptos o la jurisprudencia que se reputan infringidos se ha aplicado con carácter retroactivo, en un momento en que aquella exigencia no era conocida ni predecible a tenor de la jurisprudencia precedente. El Tribunal Constitucional le dará la razón y ello, entre otros factores, precisamente por

21 Sobre ello, García Andrade (2016). 
la advertencia previa que hizo en los prolegómenos ante la Audiencia Nacional. A juicio del Pleno quedaba constatada por ello la diligente respuesta del demandante al presentar comunicación previa para adecuar el anterior escrito de preparación. Este podía estar mejor o peor expresado en los términos de la nueva obligación de la doctrina del Supremo, pero, lo cierto es que evidenciaba, de algún modo - como dice el Tribunal Constitucional—, la diligencia de la parte en este sentido. Y así, nos dice el Pleno: «La parte recurrente extremó su diligencia para dar cumplimiento a todos los requisitos procesales exigidos por la jurisprudencia de la Sala, incluidos los que habían sido añadidos por el cambio de su doctrina sobre la admisión, tomando la iniciativa de presentar un escrito complementario de adecuación a las nuevas exigencias y, pese a ello, el Tribunal sin ponderar las circunstancias concurrentes - la diligencia con la que actuó la recurrente, la imposibilidad de cumplir con los requisitos procesales en el momento procedente y la satisfacción de las finalidades del escrito de preparación a través del escrito de adecuación presentado- inadmitió el recurso, por lo que puede concluirse que el Tribunal Supremo no dio una respuesta racional adaptada al caso sometido a su enjuiciamiento. Ciertamente, si el demandante no hubiera satisfecho dicha carga procesal, acomodándose al cambio jurisprudencial con la presentación del referido escrito, la conclusión que habríamos alcanzado sería precisamente la contraria, desestimando la invocada vulneración». Y téngase en cuenta que la novedad que ha supuesto esta doctrina del Tribunal Constitucional ha servido para otorgar el amparo en otros casos de inadmisión de un recurso de casación por defectos en el escrito de preparación en los términos de la nueva doctrina del Supremo (SSTC 17/2015 [Sala Segunda] y 20/2015 [Sala Segunda], de 16 de febrero, 37/2015 [Sala Primera] y 38/2015 [Sala Segunda], de 2 de marzo, 52/2015 [Sala Primera], de 16 de marzo, 64/2015 [Sala Primera], de 13 de abril, y 139/2015 [Sala Primera], de 22 de junio) ${ }^{22}$.

Sobre el tema de la denegación del derecho a la asistencia jurídica gratuita encontramos la STC 90/2015 (Sala Segunda), de 11 de mayo de 2015. Este fallo analiza el caso de un recurrente que en primera instancia pudo litigar porque actuó con la ayuda desinteresada de profesionales amigos que renunciaron a cobrar sus honorarios. En apelación no gozó de dicha ayuda, razón por la cual solicitó acogerse al beneficio de justicia gratuita del art. 119 de la Constitución, pero la Comisión de Asistencia Jurídica Gratuita de la provincia de Valencia denegó tal petición bajo el argumento de que se solicitaba tal beneficio para recurrir en apelación, por lo cual entendía que, habiendo tenido medios para pagar al letrado en instancia previa, debía tenerlos también

22 Sobre ello, Lozano Cutanda (2015). 
en apelación. Naturalmente, el Tribunal reconoce el derecho de la recurrente a la tutela judicial efectiva del art. 24 de la Constitución, en su vertiente del derecho a los recursos legamente previstos y en relación con el derecho a la gratuidad de la justicia del art. 119. A juicio de la Sala, el matiz de la colaboración de amigos y conocidos en la primera instancia, «así como el dato sobrevenido de la necesidad de pago de tasas en apelación, cuya exigencia no era obligatoria cuando inició el proceso, debieron ser ponderadas por la Comisión de Asistencia Jurídica Gratuita a la hora de adoptar su decisión; al no hacerlo así e ignorar completamente tales argumentos, se vulneró el derecho a la tutela judicial efectiva de la recurrente, ya que la decisión carece de una motivación suficiente y es consecuencia de una interpretación restrictiva del derecho fundamental en juego, que no era otro que el derecho a los recursos legalmente previstos, puesto que la decisión de denegar tal beneficio impidió a la parte recurrente acceder al recurso de apelación en el pleito principal». La misma jurisprudencia se repite en la STC 124/2015 (Sala Segunda), de 8 de junio de 2015, en un caso de igual tenor, donde en primera instancia se había producido una renuncia expresa de honorarios por parte de la letrada.

\subsection{Derecho a la legalidad}

En materia de vulneración del derecho a la legalidad sancionadora, con resultado desestimatorio, cabe mencionar la STC 146/2015 (Pleno), de 25 de junio. Los hechos de los que trae origen la causa tienen base en una inspección de la Delegación Especial de Canarias que emite informe respecto de un empresario afirmando, grosso modo, que su empresa era un mera estructura diseñada con el único propósito de defraudación tributaria mediante la emisión de facturas falsas; luego le imponía una sanción económica millonaria. Ante dicha decisión acude al Tribunal Económico-Administrativo Central, con resultado negativo y, después, por vía de recurso contencioso-administrativo ante la Sala de lo Contencioso-Administrativo de la Audiencia Nacional, que también desestima su petición. Contra las decisiones administrativas previas y la resolución en vía contencioso-administrativa que las ratifica, el sujeto solicita amparo. Según él, se había producido por estas resoluciones una vulneración del derecho a la legalidad penal y sancionadora (art. 25.1 de la Constitución), en relación con los arts. 201.1, 3 y 5 de la Ley 58/2003, de 17 de diciembre, General Tributaria, y con los arts. 392 y 390.1 y 2 del Código Penal. A su juicio, la conducta consistente en expedir facturas falsas por quien no es empresario y no ha desarrollado una actividad empresarial solo puede ser castigada en vía penal, subsumiéndola en el tipo delictivo del art. 390.1.2 del Código Penal, pero nunca en vía administrativa (en el tipo agravado del art. 201.3 de la Ley 58/2003). El Tribunal no comparte esta 
opinión. A juicio del Pleno, el análisis de la disyuntiva no solamente debe hacerse desde una perspectiva penal, como hace el recurrente, sino, más bien, desde la aplicabilidad del art. 201 de la Ley 58/2003, General Tributaria. A ojos del Pleno, lo que el precepto tipifica es el «incumplimiento de la obligación de facturación", que se realiza en cualquier caso por "la emisión de facturas con datos falsos o falseados por quien ejerce una actividad empresarial o profesional como por quien no la ejerce, pues ambas actuaciones vulneran deberes de facturación que aquella norma impone a los sujetos pasivos, sean o no empresarios o profesionales». Por decirlo de algún modo más coloquial, para el Pleno, en el fondo, para la norma es indiferente que aquel que realiza el tipo sea un empresario o sea una persona con disfraz de empresario. Desde este planteamiento, el Tribunal también desdice que se haya vulnerado el derecho del recurrente a la legalidad penal y sancionadora, puesto que el art. 201.3 de la Ley General Tributaria califica taxativa y muy claramente como «muy grave» la conducta tipificada en el art. 201.1 del mismo texto legal (el incumplimiento de las obligaciones de facturación) cuando el incumplimiento consista en la expedición de facturas "con datos falsos o falseados». En este sentido la subsunción de la acción del recurrente en el tipo «no puede considerarse que violente los términos del precepto aplicado, ni desde la perspectiva literal, ni desde el punto metodológico, ni, en fin, desde el prisma axiológico, pues, como señalan uno y otro, una factura falsa, por no responder a realidad alguna, no es sino una factura con todos sus datos falsos».

\section{RECAPITULACIÓN Y CONCLUSIONES}

El análisis de la presente selección de resoluciones del Tribunal Constitucional nos vuelve a dejar comprobar muy bien cómo, durante 2015, también se ha desplegado, por parte de este instituto, de forma sobresaliente, el control de la eficacia normativa de la Constitución. En particular hay que destacar la labor continua del Tribunal en su labor de perfilación del Estado autonómico, de examen de la disociación de competencias e intereses Estado-autonomías y de garantía de los derechos de los ciudadanos también frente a los excesos de las comunidades autónomas. En este sentido, quizás destacan sus decisiones en materia de control de la facultad impositiva de las comunidades autónomas, por ejemplo, las SSTC 30/2015, de 19 de febrero, 107, 108 y 111/2015, de 28 de mayo y 202/2015, de 24 de septiembre. Ciertamente, las comunidades autónomas han sufrido y sufren, como el Estado, las circunstancias y restricciones que han llevado a un importante ajuste de todas las instituciones y administraciones. Y, por supuesto, las comunidades autónomas tienen legítimas facultades tributarias, pero dentro de los criterios establecidos en la 
Constitución y, en particular, en la Ley Orgánica 8/1980, de 22 de septiembre, de Financiación de las Comunidades Autónomas; pero también, más allá, dentro del límite ético de evitar excesos impositivos a sus ciudadanos, facilitando, en la medida de lo posible, su ahorro y sus posibilidades de gasto. Las sentencias citadas para evitar la doble imposición o controlar las posibilidades tributarias de las comunidades autónomas son un ejemplo en este sentido, a saber, de las posibilidades fiscalizadoras del Tribunal Constitucional también a estos efectos. Y, además, es muy posible que esta línea de control continúe, si nos atenemos a la creciente tendencia a la creación de cánones y gravámenes por algunas autonomías ${ }^{23}$, como también por la continua necesidad de nueva financiación del Estado central de alguna comunidad autónoma, como es, por ejemplo, el caso de Cataluña ${ }^{24}$.

Por otra parte, en relación con la hermenéutica de los derechos fundamentales, cabe destacar su exégesis posibilista, tratando de dar una solución siempre de mayor valor del derecho fundamental, dando constantemente una vuelta más pro constitutione, sin promocionar interpretaciones excesivamente rigoristas de la norma de desarrollo y buscando la mayor eficacia de protección del recurso de amparo. Ejemplos de esta línea interpretativa generosa y dúctil son, por ejemplo, la STC 42/2015, de 2 de marzo, en materia del art. 17.4 de la Constitución, que ofrece una visión extensiva del recurso de habeas corpus, continuadora de su doctrina sentada en las SSTC 12/2014, de 27 de enero, y 21/2014, de 10 de febrero. La STC 145/2015, de 25 de junio, sobre la objeción de conciencia, la STC 54/2015, de 16 de marzo, que hace extensivas las garantías de la inviolabilidad del domicilio a situaciones parejas de entrada por investigaciones económicas; y, por otra parte, la STC 77/2015, de 27 de abril, que hace abstracción de peregrinos requisitos de forma, podrían servir aquí, entre otros, de muestras significativas de esta tendencia hermenéutica.

23 Cataluña es la comunidad que más tributos, cánones y gravámenes ha creado a fecha de 2016. Véase, con datos, REAF-REGAF (2016: 263-269, 307-310). Cataluña, por tanto, es también la comunidad autónoma con mayor presión tributaria de España. Véase así Berecher, C. (2016: 5, 25).

24 El Estado ha inyectado 43343 millones de euros a la comunidad autónoma de Cataluña, que representa el $33 \%$ de su deuda consolidada. Véase, con cifras, el Boletín Estadístico del Banco de España, marzo 2016, p. 235, cuadro 13.6. Véanse las noticia «Las cuentas de Cataluña bajo mínimos: El Gobierno anticipa 120 millones para pagar nóminas», en ABC, edición de 5 de septiembre de 2012, p. 22; «Junqueras pide auxilio para evitar la quiebra», en el rotativo El Mundo, edición de 9 de marzo de 2016, p. 10. Para más datos y cifras, véase Oehling de los Reyes y De Benito Aramburu (2016). 


\section{BIBLIOGRAFÍA}

Alenda Salinas, M. (2008). La píldora del día después su conflictividad jurídica como manifestación de la objeción de conciencia farmacéutica. Revista General de Derecho Canónico y Derecho Eclesiástico del Estado, 16, 2.

Alenza García, J. F. (2016). Las energías renovables ante la fugacidad legislativa. A propósito de la STC 270/2015 sobre el nuevo sistema retributivo de las energías renovables. Actualidad Jurídica Ambiental, 3, 1-19.

Arbós Marín, X. (2015). Una sentencia previsible. El País, 26-2-2015, 11.

Berechet, C. (2016). Informe Día de la liberación fiscal 2016. Madrid: Unión de Contribuyentes.

Del Guayo Castiella, I. (2016). La Carta Internacional de la Energía en 2015 y las energías renovables A propósito del Laudo de 21 de enero de 2016. Cuadernos de Energía, 47, 50-56.

Elvira Perales, A., Gómez Lugo, Y., Pajares Montolío, E. J., Fraile Ortiz, M. y Espinosa Díaz, A. (2015a). Actividad del Tribunal Constitucional: relación de sentencias dictadas durante el primer cuatrimestre de 2015. Revista Española de Derecho Constitucional, 104, 171-199.

- (2015b). Actividad del Tribunal Constitucional: relación de sentencias dictadas durante el segundo cuatrimestre de 2015. Revista Española de Derecho Constitucional, 105, 171-193.

- (2015c). Actividad del Tribunal Constitucional: relación de sentencias dictadas durante el tercer cuatrimestre de 2015. Revista Española de Derecho Constitucional, 106, 305-332.

García Andrade, P. (2016). Jurisprudencia española en materia de Derecho internacional público. Comentarios de sentencias. Delito de injurias a la Corona: los límites al ejercicio legítimo de la libertad de expresión y la libertad ideológica. Jurisprudencia del TEDH. Discurso del odio. Revista española de Derecho Internacional, 68 (1), 149-154.

González Hernández, E. (2016), El art. 155 CE y la LO 15/2015, de 17 de octubre de reforma de la LOTC. Teoría y realidad constitucional, 37, 529-543.

Llorente Gonzalvo, M. y López Mejía, M. (2015a). Sentencias del Tribunal Constitucional. El Notario del Siglo XXI, 59. Disponible en: http://www.elnotario.es/index. php/tribunales/3959-sentencias-del-tribunal-constitucional-numero-59.

- (2015b). Sentencias del Tribunal Constitucional. El Notario del Siglo XXI, 60. Disponible en: http://www.elnotario.es/index.php/tribunales/4041-sentencias-del-tribunal-constitucional-numero-60.

- (2015c). Sentencias del Tribunal Constitucional. El Notario del Siglo XXI, 61. Disponible en: http://www.elnotario.es/index.php/tribunales/4096-sentencias-del-tribunal-constitucional-numero-61.

- (2015d). Sentencias del Tribunal Constitucional. El Notario del Siglo XXI, 62. Disponible en: http://www.elnotario.es/index.php/tribunales/4139-sentencias-del-tribunal-constitucional-numero-62. 
- (2015e). Sentencias del Tribunal Constitucional. El Notario del Siglo XXI, 63. Disponible en: http://www.elnotario.es/index.php/legislacion/5359-sentencias-del-tribunal-constitucional-numero-63.

- (2015f). Sentencias del Tribunal Constitucional. El Notario del Siglo XXI, 64. Disponible en: http://www.elnotario.es/index.php/legislacion/5791-sentencias-del-tribunal-constitucional-numero-64.

Lozano Cutanda, B. (2015). El TC estima el recurso de amparo interpuesto contra la inadmisión de un recurso de casación por no cumplir los nuevos criterios jurisprudenciales sobre los escritos de preparación. Comentario a la STC 7/2015, de 22 de enero. Diario La Ley, 8505. Disponibe en: http://www.juntadeandalucia.es/institutodeadministracionpublica/aplicaciones/boletin/publico/boletin65/Articulos_65/ Lozano-Cutanda(2015_03_23).pdf.

Maroto Illera, R., Mulas-Granados, C. y Fernández Álvarez, J. (2012), Crisis financiera y rescates bancarios en Europa: ideas sobre el caso español. Madrid: Fundación Ideas.

Oehling de los Reyes, A. (2014), Crónica de la jurisprudencia constitucional española en el año 2013. Anuario Iberoamericano de Justicia Constitucional, 18, 533-586.

- (2015), Crónica de la jurisprudencia constitucional española en el año 2014. Anuario Iberoamericano de Justicia Constitucional, 19, 531-564.

- y De Benito Aramburu, J. M. (2016). La modificación del art. 135 de la Constitución española de 1978: aproximación jurídico-económicas las causas para una racionalización, estado de situación y resultados. Estudios de Deusto, 64 (1), 97-136.

REAF-REGAF (2016). Panorama de la Fiscalidad Autonómica y Foral 2016. Madrid: REAF-REGAF, Consejo General de Economistas.

Requejo Pagés, J. L., Duque Villanueva, J. C., Ortega Carballo, C., y Ahumada Ruiz, M. (2015a). Doctrina del Tribunal Constitucional durante el primer cuatrimestre de 2015. Revista Española de Derecho Constitucional, 104, 201-242.

- (2015b). Doctrina del Tribunal Constitucional durante el segundo cuatrimestre de 2015. Revista Española de Derecho Constitucional, 105, 195-237.

- (2015c). Doctrina del Tribunal Constitucional durante el tercer cuatrimestre de 2015. Revista Española de Derecho Constitucional, 106, 333-378.

Rodríguez-Piñero y Bravo-Ferrer, M. (2015). La inadmisión del recurso de amparo y el Convenio Europeo de Derechos Humanos. Diario La Ley, 8503. Disponible en: http://www.juntadeandalucia.es/institutodeadministracionpublica/aplicaciones/ boletin/publico/boletin65/Articulos_65/Rodriguez-Pinero-Bravo-Ferrer.pdf.

Tajadura Tejada, J. (2015). Objeción y Estado de Derecho. El País, 21-7-2015.

Tejedor Bielsa, J. C. (2015). El saneamiento del sistema financiero como límite a la competencia autonómica sobre vivienda. Comentario a la Sentencia del Tribunal Constitucional 93/2015, de 14 de mayo. Práctica urbanistica: Revista Mensual de Urbanismo, 137, 48-53.

Tribunal Constitucional (2015). Tribunal Constitucional. Memoria 2014. Madrid: Boletín Oficial del Estado. Disponible en: http://www.tribunalconstitucional.es/es/ tribunal/memorias/Documents/MEMORIA_TC_2104.pdf. 